Article

\title{
The Devil's in the Details: Evaluating the One Person, One Vote Principle in American Politics
}

Jeffrey W. Ladewig ${ }^{1}$ and Seth C. McKee ${ }^{2}$

${ }^{1}$ Department of Political Science, University of Connecticut, 365 Fairfield Way, Storrs, CT 06269, USA;

E-Mail: jeffrey.ladewig@uconn.edu

2 Department of Political Science, Texas Tech University, 113 Holden Hall, Lubbock, TX 79409, USA;

E-Mail: sc.mckee@ttu.edu; Tel.: +1-806-834-1880; Fax: +1-806-742-0850

\section{How to Cite this Article}

Ladewig, J. W., \& McKee, S. C. (2014). The Devil's in the Details: Evaluating the One Person, One Vote Principle in American Politics. Politics and Governance, 2(1), 4-31.

\section{Copyrights}

(C) 2014 by the authors; licensee Cogitatio (Lisbon, Portugal). This article is licensed under a Creative Commons Attribution 4.0 International License (CC BY).

\section{Published by: \\ COGITATIO}

www.cogitatiopress.com

\begin{abstract}
About the Journal
Politics and Governance is an innovative new offering to the world of online publishing in the Political Sciences. An internationally peer-reviewed open access journal, Politics and Governance publishes significant, cutting-edge and multidisciplinary research drawn from all areas of Political Science.
\end{abstract}

www.cogitatiopress.com/politicsandgovernance

\section{Editors-in-Chief}

Professor Andrej J. Zwitter, Faculty of Law, University of Groningen, The Netherlands

Professor Amelia Hadfield, Department of Psychology, Politics and Sociology, Canterbury Christ Church University, UK

Mr. António Vieira, Politics and Governance, Cogitatio Press, Portugal 
Article

\title{
The Devil's in the Details: Evaluating the One Person, One Vote Principle in American Politics
}

\author{
Jeffrey W. Ladewig ${ }^{1}$ and Seth C. McKee ${ }^{2, *}$ \\ ${ }^{1}$ Department of Political Science, University of Connecticut, 365 Fairfield Way, Storrs, CT 06269, USA; \\ E-Mail: jeffrey.ladewig@uconn.edu \\ 2 Department of Political Science, Texas Tech University, 113 Holden Hall, Lubbock, TX 79409, USA; \\ E-Mail: sc.mckee@ttu.edu; Tel.: +1-806-834-1880; Fax: +1-806-742-0850 \\ * Corresponding author
}

Submitted: 3 September 2013 | In Revised Form: 28 February 2014 | Accepted: 10 March 2014 |

Published: 14 April 2014

\begin{abstract}
Ever since the Supreme Court instituted the one person, one vote principle in congressional election s based on its decision in Wesberry v. Sanders (1964), intrastate deviations from equal district populations have become smaller and smaller after each decennial reapportionment. Relying on equal total population as the standard to meet the Court's principle, though, has raised some constitutional and practical questions stemming from, most basically, not every person has the right to vote. Specifically, there is considerable deviation between the current redistricting practices and a literal interpretation of this constitutional principle. This study systematically analyzes the differences between districts' total populations and their voting age populations (VAPs). Further, we consider how congressional reapportionments since 1972 would change if, instead of states' total populations, the standard for reapportioning seats were based on the VAP or the voting eligible population (VEP). Overall, the results indicate that the debate surrounding the appropriate apportionment and redistricting standard is not just normative, it also has notable practical consequences.
\end{abstract}

\section{Keywords}

equal population; malapportionment; reapportionment; redistricting; U.S. House elections; voting eligible population; voting age population

\section{Issue}

This article is part of a regular issue of Politics and Governance, edited by Professor Andrej J. Zwitter (University of Groningen, The Netherlands) and Professor Amelia Hadfield (Canterbury Christ Church University, UK).

(C) 2014 by the authors; licensee Cogitatio (Lisbon, Portugal). This article is licensed under a Creative Commons Attribution 4.0 International License (CC BY).

\section{Introduction}

It is no surprise that the question of representation has been one of the greatest concerns at and since the Constitutional Convention. The laws establishing the number of representatives and their electoral jurisdictions determine, in part, which voters have the most influence in affecting the political process and by extension the type, quality, and tenor of representation. Both congressional reapportionment and redistricting are currently guided - though to varying degrees-by the principle, as solidified by the 14th Amendment, of population equality as determined by the total number of enumerated individuals within a state or district, respectively. But, American legal history is replete with examples of challenges to how political equality is defined and implemented. These include normative, legal, political, and computational issues and each may have profound practical consequences.

In this study we address some of the potential consequences of some of the challenges to the current standards and definitions used for congressional apportionment and redistricting. 
First, we briefly explore the historical changes to and the debates over these standards and definitions. In doing so, we argue that although congressional apportionment and redistricting are, of course, distinct processes with their own legal foundations, there are still a number of normative, constitutional, and empirical ties between them, which leaves open the possibility of future changes to them and makes an alternative analysis of each a worthy endeavor.

Second, we empirically assess the one person, one vote principle in American redistricting by comparing the legal status quo of total population equality to an alternative measure: voting age population (VAP). We do so for when the use of VAP is legally required in determining majority-minority districts, as well as when it is not, in evaluations of the one person, one vote principle.

Third, while acknowledging the constitutional difficulties of such a change, we empirically assess congressional apportionment by comparing the legal status quo of apportioning U.S. House seats according to total population to the consequences of apportioning on VAP or voting eligible population (VEP).

Fourth, we empirically evaluate the one person, one vote standard as applied to congressional apportionment for all three of these population measures. Fifth, we estimate the effect that any of these apportionment changes would have on the distribution of Electoral College votes.

Overall, the intrastate analyses show that despite notable reductions in district deviations from equal total population, there has not been a corresponding decline in deviations away from equal voting age population. The interstate analyses reveal that reapportionments based on the VAP and VEP would considerably alter the redistribution of U.S. House seats and this would marginally benefit the Democratic Party in presidential elections.

\section{The Defining of "Total Population" and "One Per- son, One Vote"}

As any introductory American government textbook explains, the issue of representation carried the most importance among the various debates at the 1787 Constitutional Convention. The opposing positions of delegates representing large states (i.e., Virginia) and small states (i.e., New Jersey) were eventually resolved, appropriately enough by the Connecticut Compromise, a medium-sized state led by Roger Sherman, who successfully advocated for an upper chamber with representation set at two Senators per state and a lower chamber whose representation was based on a state's population. This "Great Compromise" not only mollified the opposition to tying representation to population in one chamber, but just as fundamental, by denoting slaves as three-fifths of a person in the apportionment process, the opposing interests of northern and southern delegates were temporarily assuaged. In many important and fundamental ways, achieving this compromise did not preclude, of course, many highly contested subsequent political battles and changes in an attempt to make congressional representation, among other things, align more closely with the founding's democratic ideals.

The most significant and obvious change to congressional apportionment occurred with the passage of the 14th Amendment to the Constitution in 1868, which repealed the "original sin" of the Great Compromise and finally included all African Americans as whole persons in the apportionment of seats to the U.S. House of Representatives. But much of 19th and early 20th century American history is replete with other contestations of congressional apportionment, such as over which apportionment formula is fairer as well as when and where to add "bonus" seats (Balinski \& Young, 2001). For instance, after the 1870 Census, 283 seats were apportioned by population while an additional nine seats were added to a few states as a political favor. The distribution of these resulting 292 seats was not possible with either of the apportionment formulas used at the time and these bonus seats ended up making the difference in the 1876 presidential election. Despite many changes in the formula and except for the few bonus seats, since 1868 congressional apportionment has been assigned to each state according to their total population.

Yet, the definition of "total population" since passage of the 14th Amendment continues to undergo changes and challenges (Anderson, 1988). For example, it was not until 1940 that the U.S. Attorney General declared that all Native Americans were considered taxed and thus all were included in the apportionment enumeration by the U.S. Census (39 Op. Att'y Gen. 518 (1940)). And, the definition of a state's total apportionment population was officially augmented in 1970, but not in 1980, and was again from 1990 to the present defined to include some individuals overseas. This includes U.S. military personnel as well as Federal civilian employees and their dependents living with them. Others who are overseas, such as the Merchant Marines, fishing trawlers, floating processers, tuna boats, etc., were counted in their state's total population, but not included in the state's apportionment total populations (Mills, 1993)..$^{1}$ Interestingly, none of these overseas populations are included in the "total populations" used for redistricting.

\footnotetext{
${ }^{1}$ The definition and inclusion of the overseas populations is more complicated and nuanced than the summary text description. For instance, many overseas individuals were simply added to the Census counts in 1870,1880, and 1900. After the 1990 Census, the Commonwealth of Massachusetts sued to exclude overseas populations. The Supreme Court, in Franklin v. Massachusetts (1992), declared their inclusion constitutional.
} 
Also, more recently, there have been Supreme Court challenges to the Census's calculation of total population and its use of data imputation, statistical sampling, and the use of unadjusted figures (see Utah v. Evans 2002; Department of Commerce v. United States House 1999; Wisconsin v. City of New York et al. 1996) as well as to the constitutionality of including non-immigrant foreign nationals in a state's apportionment enumeration (Louisiana v. Bryson 2011). In sum, while the standard for congressional apportionment of total population is defined in the Constitution and would likely require a constitutional amendment to considerably alter it, we also should not think of it as immutable.

Whatever the definition of and the procedures used to calculate the total population of a state, that figure (based on the apportionment formula) is then used to allocate to each state its number of U.S. House seats. And, the districting of those seats within a state has witnessed a history of contestations similar to those associated with apportionment. For instance, intrastate population equality among districts was not a particularly valued principle for much of the first half of the 20th century; in fact, northern and southern politicians alike often actively opposed any change toward greater equality. Both parties had many districts outside of major urban centers with proportionally fewer residents; these rural voters' interests, thus, received outsized attention (Ansolabehere, Gerber, \& Snyder, 2002). In partisan terms, this meant that congressional districts in the North were often biased in favor of Republicans and U.S. House boundaries in the South perpetuated the longstanding hegemony of rural Democrats (Cox \& Katz, 2002). Rare was the state that considered redistricting in accordance with population equality. Rather the status quo was generally upheld, and this included often incorporating newly apportioned U.S. House seats as at-large districts-covering the entire state.

Failure to adjust district boundaries to satisfy a principle of population equality was met with growing resistance among those constituents residing in more populous metropolitan settings, and in 1946 the Supreme Court addressed the issue of district malapportionment. In the famous 4-to-3 decision handed down by Justice Frankfurter in Colegrove v. Green, the Supreme Court chose not to wade into the "political thicket" of setting the criteria for crafting legislative districts. The ruling in this case was not, of course, the last word, and in the 1962 Baker v. Carr decision not only did the Court deem redistricting a justiciable issue but also endorsed a principle of apportionment based on the criterion that each person deserved an equal vote (Levinson, 1985). Hence the principle of one person, one vote was established.

On its face, the notion and conception of the one person, one vote principle seems straightforward and hardly controversial-much like "total population". Court rulings and scholarly opinions, however, have here too injected considerable nuance and complexity as to what this tenet actually means in reconfiguring these districts following the decennial Census and subsequent apportionment. If we merely take the principle at its word, for example, we might expect that equal representation demands a remarkably precise distribution of voters-indeed, such that an equal number of voters populate each district in any state that contains enough residents to warrant multiple districts. But from this seemingly simplistic interpretation the matter is complicated by two realities, one legal and the other empirical.

First, legal precedent has never held that redistricting in accordance with the one person, one vote principle should be tied to anything other than some definition of total population-regardless of how many actual voters are present. No finer differentiation of the defined total population-such as, based on age, citizenship, or any other criterion-has become the default standard in determining congressional redistricting. Yet, the Court has allowed, in a few particular cases, districting arrangements that are performed on the basis of a finer measure of voter equality than simple total population. For example, in the 1966 case of Burns v. Richardson the Court agreed "that a jurisdiction could satisfy one-person, one-vote by drawing districts...[with] equal numbers of registered voters" (quoted in Persily, 2011).

Despite opening this legal possibility, in the ruling of the 2011 case of Lepak v. City of Irving, which the Supreme Court declined to hear, the Fifth Circuit United States Court of Appeals refused to overturn the reapportionment plan for the city council districts even though the one majority Hispanic district was approximately equal to its counterparts with respect to total population but almost half as large if the measure is based on the citizen voting age population. This north Texas municipality is an instance where the one person, one vote principle - as typically interpreted - is upheld, while it - as literally interpreted-appears to be violated. In other words, Irving, Texas achieved total population equality among its districts while undermining voter equality. Its actions may empower a minority population, but it does so, ironically, at the expense of diluting the votes of the majority segment of Anglo residents. Hence, on the most basic level, there seems to be some tension between the Court's jurisprudence and possible interpretations of the classic democratic principle of one person, one vote.

This ties directly into the second issue that the one person, one vote principle must contend. Not only do finer measures of voter equality entangle the legal profession in debates about salient tradeoffs regarding, for instance, minority representation, but the Census is also not currently administered and designed in 
such a manner that it can adequately extract reliable data on voter eligibility or citizenship at finer levels of political geography, including congressional districts (Persily, 2011) ${ }^{2}$. Thus, if we again take the notion of one person, one vote in its most literal sense and desire the redistribution of voters in geographic settings so that these boundaries contain the same number of eligible voters or citizens, we cannot, at least at this time, perform such a task because the data are not there.

Beyond the issues with legal precedents and empirical limitations, we should also state the commonly understood reality that a Census count constitutes no more than a static picture of the population conducted over a very short span of time. In other words, even if we are confident in the Census count of the American population (admittedly this is a big "if"), it is of course dynamic - with tremendous variation in residential mobility, incarceration rates, birth rates, death rates, migration, and all of these components varying by differences in the demography of any given locality. This reality obviously also serves to undermine any attempt to meet the one person, one vote principle. In other words, the moment the Census is completed, it is outdated.

It is then, at least, a curiosity that the Court has used the slogan of "one person, one vote" to label their position first established in Baker v. Carr (1962) and reinforced since the 1960s. But, there are reasons to think that it could be more than just a curiosity. There are creditable arguments that a standard narrower than total population-and more closely aligned with the number of actual voters - better models some democratic norms (Fishkin, 2012). ${ }^{3}$ And, there is some legal precedence for these prescriptions as well. For

\footnotetext{
${ }^{2}$ In the same article, Persily explains the shortcomings of Census data on the number of citizens in a given locality at lower levels of geographic aggregation. For one, the Census data for congressional redistricting do not indicate citizenship and, in order to make estimates at the congressional district level requires use of American Community Survey (ACS) data, which is not reliable because the surveys are not representative of constituents residing in America's 435 U.S. House districts. So, with regard to considering estimates of, for example, the Latino citizen voting age population (CVAP), Persily concludes that "the only relevant citizenship data available from the census gives ballpark figures, at best, and misleading and confusing estimates at worst" (p. 776).

${ }^{3}$ Explicitly, we mean that one person who is able to vote (eligible) should have a commensurate influence (weight) given to their vote in District $X$ as the weight afforded another eligible voter situated in District $Y$. Admittedly, the proposition that a single voter has much (if any) influence on affecting who represents them is miniscule to the point of approximating zero and hence it is really a matter of the aggregation of eligible voters in any two districts in a given state being as equal as possible. For an interesting critique of the notion that votes for individuals should essentially carry the same weight see Fishkin (2012). Fishkin recognizes that with the vast expansion of the eligible electorate, the courts have moved away from defending the principle of virtual representation (that minors and others ineligible to vote deserve equal representation) and decidedly in favor of a one person, one vote standard predicated on the population of eligible voters.
}

example, the Voting Rights Act defines majorityminority districts by VAP, not total population.

To be clear, congressional apportionment and redistricting are two distinct processes with largely distinct legal foundations, but they do share similar normative and empirical goals and use similar data to try to achieve them. The use of total population in congressional apportionment is constitutionally codified by the 14th Amendment, though its definition has historically been somewhat malleable. Once each state is notified of the number of congressional districts it has been apportioned for the next decade, it is required by the jurisprudence of the Supreme Court to construct its districts in accordance with the one person, one vote principle-that is, each district is to have "as mathematically equal as reasonably possible" the same portion of the state's total population (quoted in White $v$. Weiser, 1973).

Although the redistricting total population can have the same intertemporal malleability as the apportionment total population, there are currently also slight differences between them (e.g., the overseas populations are excluded from the former). Nonetheless, both processes rest on a similar normative and constitutional understanding. Intrastate congressional redistricting was brought under the one person, one vote principle in the 1964 Wesberry v. Sanders decision: "the command of Art. I, 2, that Representatives be chosen "by the People of the several States' means that as nearly as is practicable one man's vote in a congressional election is to be worth as much as another's". And, the Court, in Department of Commerce v. Montana (1992), tentatively connected this same principle to interstate congressional apportionment: "there is some force to the argument that the same historical insights that informed our construction of Article I, 2, in the context of intrastate districting should apply here as well. As we interpreted the constitutional command that Representatives be chosen 'by the People of the several States' to require the State to pursue equality in representation, we might well find that the requirement that Representatives be apportioned among the several States 'according to their respective Numbers' would also embody the same principle of equality".

All of the above normative, legal, definitional, and empirical interconnections between and variations within congressional apportionment and redistricting continue to leave open the possibility-as slight as it may be-that the application of the democratic and constitutional principle of one person, one vote could continue to be challenged and maybe even augmented for one or both of them in the future. To better understand some of the possible empirical consequences, the remainder of this article agnostically exploreswith the best available data, some of which is unfortunately limited-the recent history of U.S. congressional apportionment and redistricting (1972-2012). We 
compare and contrast the current legal standard of total population with the implications of applying a more literal definition of one person, one votespecifically the use of voting age population and voting eligible population to assess the degree of intrastate and interstate malapportionment in American politics.

\section{The Reapportionment Revolutions}

In this section we discuss the historical and political contexts that shaped the legal arguments propping up the two major pillars guiding contemporary congressional redistricting: equal population and safeguards for minority voting rights.

Scholars speak of Baker v. Carr as initiating a revolution (Cox \& Katz, 2002; Fenno, 1978), because of its wide reaching effects on district-based elections. The reassignment of residents on the basis of equal population clearly could and would, alter the outcomes of elections both in terms of the incumbency advantage (Desposato \& Petrocik, 2003) and partisan control (McKee, 2008). But this was not the only reapportionment revolution. Thirty years after Baker v. Carr, with the equal population rule firmly in place, the second reapportionment revolution occurred with the massive increase in the number of majority-minority districts created for the 1992 congressional elections (McKee, 2004).

The principle guiding the first reapportionment revolution was of course technically colorblind, but the context surrounding its advocacy had much to do with the issue of race (Levinson, 2002). Especially in southern states, congressional district populations variedly enormously (Bullock, 2010). This was not by accident, rather the historical strength of the Democratic Solid South resided in rural counties that often contained relatively large, and primarily disfranchised, African American populations (Key, 1949). The whites in these rural settings knew that readjustment of district boundaries on the basis of equal population would weaken their hold on political power. Not surprisingly, the triumvirate of cases (Baker v. Carr; Reynolds v. Sims; and Wesberry v. Sanders) forming the backbone of the one person, one vote principle involved lawsuits from southern states (Tennessee, Alabama, and Georgia, respectively). Redrawing district lines to better suit the one person, one vote principle would eventually bolster the clout of African Americans (Bullock \& Gaddie, 2009) and whites residing in burgeoning metropolitan areas (Black \& Black, 2002).

Enforcement of the equal population standard as espoused in Baker, centered on the simple counting of the number of people residing in a given district. As we will demonstrate, compliance with this standard has increased with every subsequent reapportionment in response to essentially a zero-tolerance policy laid out by the Supreme Court in Karcher v. Daggett (1983). In this case the Court ruled that even miniscule deviations from equal total population violated the Constitution because the state of New Jersey could clearly comply with implementing a plan with more equal district populations. Specifically, the population difference between the largest and smallest congressional district in New Jersey was 3,674 individuals, which was just $0.7 \%$ of the state's ideal district size.

With practically no justifiable wiggle room from the equal total population standard established by the Court in Karcher, the question of minority vote dilution reemerged in the 1986 case of Thornburg v. Gingles. Responding to a history of southern apportionment and districting schemes that were devised to weaken the likelihood that African Americans would have the opportunity to elect candidates of their choice (Davidson, 1984; Parker, 1990), in Thornburg v. Gingles ${ }^{4}$ the Supreme Court laid out a set of criteria, that if met, would allow for the creation of districts controlled by minority populations (for details see Butler, 2002; McKee and Shaw, 2005). Because of the timing of the decision, the 1992 U.S. House elections would be the first to occur with a large expansion in the number of newly created majority-minority districts.

Table 1 displays data on the number of majority black and majority Hispanic congressional districtslegally defined by a district's voting age populationfrom 1972 to 2012. Whereas there were eight majority black districts in 1972 and twelve in 1982, in the wake of the Thornburg decision the number increased to 27 in 1992. Most of the new majority black districts were located in southern states covered by the 1965 Voting Rights Act (VRA). Under the Preclearance Provision in Section 5 of the VRA, the Department of Justice oversaw redistricting plans, and during the 1990s round it insisted that certain southern states maximize their number of majority black districts (Bullock, 2010; Butler, 2002). In 2002 the total is reduced to 21 , but went up to 24 in 2012. The decline in the total number of majority black districts since 1992 is partly due to slower population growth among the African American population vis-à-vis other minority groups (especially compared to Asians and Latinos) and also a response to the Shaw v. Reno (1993) decision and subsequent rulings (e.g., Miller v. Johnson 1995; Bush v. Vera 1996; Hunt v. Cromartie 2001) that declared several majority black districts unconstitutional racial gerrymanders (Butler, 2002).

In contrast with majority black districts, the large jump in the number of majority Hispanic districts from 1982 (N =6) to $1992(\mathrm{~N}=16)$ is followed by another increase from 21 in 2002 to 30 by 2012. Also, since 1982, the average percent Hispanic VAP (HVAP) increases and it is notably higher than the average percent black VAP (BVAP) in these years in these majority-minority districts.

\footnotetext{
${ }^{4}$ This was a North Carolina case.
} 
Table 1. Majority Black and Majority Hispanic U.S. House Districts, 1972 to 2002.

\begin{tabular}{|c|c|c|c|c|c|}
\hline Statistics & 1972 & 1982 & 1992 & 2002 & 2012 \\
\hline \multicolumn{6}{|c|}{ Majority Black Districts } \\
\hline Average BVAP & $66 \%$ & $66 \%$ & $59 \%$ & $57 \%$ & $54 \%$ \\
\hline Median BVAP & 62 & 66 & 58 & 57 & 54 \\
\hline Maximum BVAP & 86 & 90 & 72 & 63 & 61 \\
\hline Minimum BVAP & 58 & 51 & 50 & 51 & 50 \\
\hline Range & 28 & 39 & 22 & 12 & 11 \\
\hline Standard Deviation & 10 & 11 & 6 & 3 & 4 \\
\hline $\mathrm{N}$ & 8 & 12 & 27 & 21 & 24 \\
\hline \multicolumn{6}{|c|}{ Majority Hispanic Districts } \\
\hline Average HVAP & $60 \%$ & $57 \%$ & $61 \%$ & $64 \%$ & $64 \%$ \\
\hline Median HVAP & 60 & 56 & 58 & 64 & 61 \\
\hline Maximum HVAP & 69 & 66 & 79 & 75 & 82 \\
\hline Minimum HVAP & 52 & 50 & 53 & 52 & 50 \\
\hline Range & 17 & 16 & 26 & 23 & 32 \\
\hline Standard Deviation & 12 & 5 & 7 & 7 & 9 \\
\hline $\mathrm{N}$ & 2 & 6 & 16 & 21 & 30 \\
\hline
\end{tabular}

Note: Data calculated by the authors from the U.S. Census Bureau. The 2012 results were computed from the data made available by Stephen Wolf as posted on the Daily Kos website: www.dailykos.com/story/2013/04/08/1200099/-113th-Congress-Guide-wDemography-Pronunciation-08-12-Pres-12-House-06-12-Downballot-by-CD

Furthermore, the maximum, range, and standard deviations of the HVAP remain much higher than the corresponding BVAP statistics for majority black districts. One obvious explanation for the differences is that Hispanic populations have much higher rates of noncitizen voting age populations.

Against the backdrop of the equal total population rule, the increase in majority-minority districts, as numerous studies have documented (Black and Black, 2002; Lublin, 1997; Epstein and O'Halloran, 1999; Hill, 1995; Petrocik and Desposato, 1998), necessarily reduced the overall number of congressional districts won by Democratic candidates. This was because minority voters, especially African Americans, are the most Democratic in their voting preferences and thus concentrating them into fewer districts increased the portion of Republican voters in adjoining districts.

The progression of case law squarely rests the metric of the one person, one vote principle on counting the total population in a state and then dividing it by the assigned number of congressional districts. By contrast, the question of apportioning districts where minority vote dilution comes into play is an everevolving legal issue. Suffice it to say that it has become a highly contentious and partisan-laden dispute because the concentration of minority populations generally benefits the Republican Party in congressional elections, at least in the aggregate (but see Shotts, 2001). And given the 2013 ruling in Shelby County v. Holder, which threw out the Section 4 criteria used for determining Section 5 preclearance under the VRA, it remains to be seen what future redistricting plans will look like and what, if any, new districting standard may be added.

To be sure, minority vote dilution remains a constitutional violation (as articulated in Thornburg $v$. Gingles 1986), but by rendering Section 4 of the VRA unconstitutional, it is likely that Republican-controlled legislatures will now be more inclined to pack minority voters (Latinos and African Americans) into fewer districts with even higher non-citizen residents and others ineligible to vote, especially in the case of Hispanics. A switch from districting based on a standard of total population to one according to VAP, for instance, would likely lessen to some extent, the effectiveness of this type of partisan gerrymander. From the vantage of Democrats seeking an electoral advantage, expect the persistence of intra-party disputes between minorities (blacks and Hispanics) and Anglos. Some minority Democrats will insist on protecting racially descriptive representation through the maintenance and further creation of majority-minority districts, whereas Anglo Democrats will advocate for less concentration of minority populations so their more equally distributed presence across multiple districts enhances the aggregate win/loss record of Democrats in U.S. House races. Changing from a total population standard to VAP would, perhaps, make Democrats even more attentive to the common tradeoff between minority representation and partisan competitiveness. 


\section{Empirical Assessments of the One Person, One Vote Principle}

We first seek to determine the extent to which congressional districts that are redistricted on the total population standard of the one person, one vote principle approximate equality when viewed by other standards.

Specifically, we begin with an analysis that shows just how much variability exists between measures of equal district total population versus one based on the district voting age population. The disparities are notable because the VAP standard gets us, arguably, closer to the literal one person, one vote ideal, which, as in the Wesberry decision, intends that "one man's [sic] vote in a congressional election is to be worth as much as another's". This, then, raises questions about the constitutionality between the goals and the means of democratic equality as pronounced by the Court.

Second, we demonstrate what the reapportionment of House seats would look like if it were based on the VAP and the VEP, instead of total population, what the resulting malapportionment is for each, and what the implications would be for the partisan allocation of Electoral Votes in presidential contests.

\section{Intrastate Deviations}

Beginning with Wesberry and continuing through current jurisprudence, the Court has insisted that U.S. House districts within a state be drawn, as mathematically as possible, with equal populations. This constitutional requirement has become increasingly refined since the 1960s equality revolution, because (1) the U.S. Census has provided considerably more microlevel data and (2) these data work in conjunction with advances in computer software technologies that employ Geographic Information Systems (GIS) to map populations. Today, the constitutional principle of population equality is interpreted for most states ${ }^{5}$ to mean that a state's congressional districts should not deviate in their apportionment population by more than a single person. ${ }^{6}$

Table 2 documents the increasing precision with which one-person, one-vote based on the total population standard - has been applied. In 1972, the first reapportionment and redistricting after Wesberry, $62.3 \%$ of congressional House districts deviated from their state's ideal district population by less than

\footnotetext{
${ }^{5}$ lowa is a notable exception. lowa passed a state constitutional amendment requiring their U.S. House districts to contain whole counties as long as the population deviations are not greater than $1 \%$. The maximum deviation in lowa's post-2010 districts was 76 individuals.

${ }^{6}$ This deviation is allowed when a state's apportioned population is not perfectly divisible by the number of congressional districts allocated to the state.
}

$0.25 \%$ and the average deviation for all House districts was $3.88 \%$. Yet, in 1972 , there were still $8.81 \%$ of districts that deviated by $1 \%$ or more from this standard and a maximum deviation of $7.34 \%$. As the Court continued to press for greater and greater equality, the rates and size of deviation dropped precipitously. After the 2012 reapportionment, 99.07\% of all House districts were within $0.25 \%$ of their state's ideal populations. In fact, the average deviation for all House districts was just $0.01 \%$; the maximum deviation was just $0.94 \%$.

For several reasons, the one-person, one-vote revolution has been a tremendous success. It eliminated the democratically corrupting practice of "silent gerrymandering" that allowed for increasingly rotten districts to proliferate as well as the partisan advantages that they engendered. It avoided the "political thicket", of which Justice Frankfurter was so fearful of in Colegrove v. Green (1946), by reengaging the political practice of redistricting. And, it reduced the deviation in apportionment populations in states' House districts to nearly zero.

Chief Justice Earl Warren, in fact, wrote in his Memoirs that the seminal Baker decision was the most important decision in his entire tenure on the Court - more so than, for instance, Brown v. Board of Education (1954), Gideon v. Wainwright (1963), or Miranda v. Arizona (1966). In summing these accomplishments, Ansolabehere and Snyder (2008) conclude that American democracy is entering an "age of fairness" and the end of inequality.

Table 2 clearly demonstrates that inequality is nearly vanquished - at least as measured by the total number of individuals in the congressional districts for each state. Nonetheless, this measure does not easily equate to the constitutional principle of one person, one vote. As Levinson (2002) argues, this principle "most certainly does not hold true either as a description of the electorate or even as a normative guide to deciding which persons should be awarded the franchise and what weight their votes should actually have in the electoral process."

In other words and in the most basic interpretation, the numerical count for the standard - the total population as defined-includes many "persons" who cannot vote, for instance, individuals below the age of 18 , individuals who are not U.S. citizens, and many felons. This is considerably more than just a semantic concern - in other words, perhaps "one person, one vote" may be more than just a poor choice of words. The constitutional and normative underpinnings of the principle are central to the efficacy of a democracy: equality and the right to vote. Levinson concludes by arguing that the constitutional principle of one person, one vote is a democratic mantra in need of a meaning. 
Table 2. Increasing Precision of the Equal Population Requirement, 1972-2012.

\begin{tabular}{|c|c|c|c|c|c|}
\hline $\begin{array}{l}\text { Percent Deviation from State } \\
\text { Average District Population }\end{array}$ & $\begin{array}{r}1972 \\
\text { (93 } 3^{\text {rd }} \text { Congress) } \\
\end{array}$ & $\begin{array}{r}1982 \\
\text { (98 } \\
\end{array}$ & $\begin{array}{r}1992 \\
\left(103^{\text {rd }} \text { Congress }\right) \\
\end{array}$ & $\begin{array}{r}2002 \\
\left(108^{\text {th }} \text { Congress }\right) \\
\end{array}$ & $\begin{array}{r}2012 \\
\left(113^{\text {th }} \text { Congress }\right) \\
\end{array}$ \\
\hline \multicolumn{6}{|l|}{ Districts with Deviations of... } \\
\hline Less than 0.25 percent & $62.38 \%$ & $77.18 \%$ & $97.18 \%$ & $98.59 \%$ & $99.07 \%$ \\
\hline 0.25 to 0.5 percent & 16.9 & 12.24 & 2.82 & 1.17 & 0.23 \\
\hline 0.5 to 1 percent & 11.9 & 7.53 & -- & 0.23 & 0.7 \\
\hline 1 to 5 percent & 8.57 & 3.06 & -- & -- & -- \\
\hline 5 percent or more & 0.24 & -- & -- & -- & -- \\
\hline Average $\%$ deviation & $3.88 \%$ & $1.93 \%$ & $0.36 \%$ & $0.01 \%$ & $0.01 \%$ \\
\hline Maximum \% deviation below & -4.81 & -1.47 & -0.46 & -0.34 & -0.67 \\
\hline $\begin{array}{l}\text { Maximum \% deviation above } \\
\text { ideal population }\end{array}$ & 7.34 & 1.65 & 0.47 & 0.66 & 0.94 \\
\hline $\mathrm{N}$ & 420 & 425 & 426 & 426 & 428 \\
\hline
\end{tabular}

Note: Data include all districts except those that were either at-large or in states that did not redistrict for the relevant election: 1972: at-large states were AK, DE, NV, ND, VT, and WY; $H I(N=2), M E(N=2), N E(N=3)$, and NM ( $N=2)$ did not redistrict for the 1972 elections. 1982: at-large states were $A K, D E, N D, S D, V T$, and $W Y ; M E(N=2)$ and $M T(N=2)$ did not redistrict for the 1982 elections. 1992 and 2002: at-large states were AK, DE, MT, ND, SD, VT, and WY; ME (N=2) did not redistrict for the 1992 and 2002 elections. 2012: at-large states were AK, DE, MT, ND, SD, VT, and WY.

Table 3. Variations in Voting Age Populations, 1972-2012.

\begin{tabular}{|c|c|c|c|c|c|}
\hline $\begin{array}{l}\text { Percent Deviation from State } \\
\text { Average District VAP }\end{array}$ & $\begin{array}{r}1972 \\
\text { (93rd Congress) }\end{array}$ & $\begin{array}{r}1982 \\
\text { (98th Congress) }\end{array}$ & $\begin{array}{r}1992 \\
\text { (103rd Congress) }\end{array}$ & $\begin{array}{r}2002 \\
\text { (108th Congress) }\end{array}$ & $\begin{array}{r}2012 \\
\text { (113th Congress) }\end{array}$ \\
\hline \multicolumn{6}{|l|}{ Districts with Deviations of... } \\
\hline Less than 0.25 percent & $4.76 \%$ & $6.35 \%$ & $6.10 \%$ & $10.80 \%$ & $7.94 \%$ \\
\hline 0.25 to 0.5 percent & 3.81 & 7.29 & 8.45 & 9.39 & 8.18 \\
\hline 0.5 to 1 percent & 10.24 & 12.47 & 15.96 & 14.55 & 16.36 \\
\hline 1 to 5 percent & 58.33 & 59.53 & 55.87 & 51.64 & 56.54 \\
\hline 5 percent or more & 22.86 & 14.35 & 13.62 & 13.62 & 10.98 \\
\hline Average $\%$ deviation & $3.53 \%$ & $2.69 \%$ & $2.58 \%$ & $2.39 \%$ & $2.26 \%$ \\
\hline Maximum \% deviation below & -16.38 & -13.26 & -13.04 & -13.06 & -10.34 \\
\hline $\begin{array}{l}\text { Maximum \% deviation above } \\
\text { ideal population }\end{array}$ & 26.77 & 17.4 & 17.31 & 17.96 & 16.17 \\
\hline Average VAP \% & $65.61 \%$ & $71.87 \%$ & $74.43 \%$ & $74.31 \%$ & $75.95 \%$ \\
\hline Minimum VAP \% & 57.31 & 60.05 & 62.29 & 63.38 & 66.81 \\
\hline Maximum VAP \% & 86.02 & 86.05 & 88.91 & 86.75 & 88.62 \\
\hline $\mathrm{N}$ & 420 & 425 & 426 & 426 & 428 \\
\hline
\end{tabular}

Note: Data include all districts except those that were either at-large or in states that did not redistrict for the relevant election: 1972: atlarge states were $A K, D E, N V, N D, V T$, and $W Y ; H I(N=2), M E(N=2), N E(N=3)$, and $N M(N=2)$ did not redistrict for the 1972 elections. 1982 : atlarge states were $A K, D E, N D, S D, V T$, and $W Y ; M E(N=2)$ and $M T(N=2)$ did not redistrict for the 1982 elections. 1992 and 2002: at-large states were AK, DE, MT, ND, SD, VT, and WY; ME (N=2) did not redistrict for the 1992 and 2002 elections. 2012: at-large states were AK, $D E$, MT, ND, SD, VT, and WY. 
Table 3 taps into this concern with the most straightforward data available for congressional districts: voting age population (VAP). Table 3 provides a similar breakdown of states' districts as Table 2, but now with the VAP as the measurement. In 1972, just $4.76 \%$ of House districts were within $0.25 \%$ of their state's ideal VAP. ${ }^{7}$ Furthermore, $81.19 \%$ of the districts had VAPs that deviated by $1.0 \%$ or more from their state's ideal VAP, of which $22.86 \%$ deviated by $5 \%$ or more. The greatest deviation in 1972 was $26.77 \%$.

The deviations in Table 2 are greatest in 1972, but the total population deviations were still considerably smaller than these corresponding VAP deviations displayed in Table 3 . In addition, the total population deviations were minimized over time, but these VAP deviations have not been systematically reduced.

In 2012, the percent of districts within the $0.25 \%$ threshold increase, but only to $7.94 \%$ - compared to $99.07 \%$ for the comparable statistic in Table 2, and $67.52 \%$ of the districts were above the $1 \%$ threshold. The maximum deviation in 2012 was $16.17 \%$.

These VAP deviations are considerable and stand in sharp contrast with the results from Table 2. Specifically, instead of witnessing the diminishing deviations in total populations over time, variations in states' district VAPs show little change over time as well as a wide variation in districts' VAP.

Together, these tables suggest that a more literal standard of one person, one vote is currently far from being met. Despite the strict overall population equality of districts within states, these figures show that some districts are "packed" with more minors who cannot vote and some with fewer minors - up to more than a $26 \%$ difference between districts within a state. In districts that are packed with relatively more minors, there are fewer remaining potential voters as compared to districts with relatively fewer minors. This results in the over-representation of the former voters and the under-representation of the latter voters.

The presence of demonstrable and predictable variation in the VAP among various societal groups —including those protected by the VRA—produces, be it random or systematic, districts of an unequal number of potential voters and thus perpetuates vote dilution. Baker and subsequent decisions declared districts with unequal populations to be unconstitutional; but this standard does not create districts in which one potential voter's vote is equal to another's.

Basing redistricting on the VAP, for instance, would create its own set of issues-most obvious

\footnotetext{
${ }^{7}$ Each state is currently required to apportion to the state's ideal population, which is calculated by dividing the state's apportionment population by the number of districts the state will have. The ideal VAP is calculated similarly, the state's total voting age population divided by the number of districts the state is allocated.
}

being greater total population deviations among districts. It would also, in all likelihood, not eliminate other measures of intrastate malapportionment. On the other hand, VAP-based allocations may arguably bring states' districts in closer compliance with the words of "one person, one vote."

\section{Interstate Deviations}

The above section documented the presence of consistent and considerable intrastate malapportionment for VAP at levels far greater than those declared unconstitutional for total population. Intrastate malapportionment, though, is but one form of malapportionment. It is the form, however, that is almost exclusively considered by the Court, politicians, and scholars. Interstate malapportionment, though, is the population deviation across the states, and as argued in the Department of Commerce v. Montana (1992) case, it very well may be susceptible to the same type of constitutional standards, tests, and proscriptions as intrastate malapportionment. And, there is plenty of evidence that the current levels of interstate malapportionment may be constitutionally suspect (Ladewig \& Jasinski, 2008; Ladewig, 2011) (also see Clemens v. Department of Commerce 2010). For example, after the 2010 reapportionment and the equalization of total populations within states (as demonstrated in Table 2), the maximum deviation in the ideal population sizes among House districts across states was still 463,132 individuals, which is $65.38 \%$ of the national ideal district size. This deviation is about $9600 \%$ larger than the deviation declared unconstitutional in Karcher and over 46 million\% larger than the typical intrastate deviation allowed today. Paradoxically, the current levels of interstate malapportionment persist and grow despite the Court's efforts in minimizing the intrastate malapportionment of the total population.

If the same one person, one vote principle of congressional redistricting also applies to congressional apportionment, then a similar critique of which standard to apply and analyze is also possible. Given that only state-level data are necessary for apportionment analyses, the data are more extensive. As such, we can conduct VAP analyses, similar to that presented in Table 3, as well as analyses based on the voting eligible population data-which are not available at the district level (thus we were not able to analyze intrastate VEP malapportionment).

Given the distribution of House seats after the 2010 reapportionment, interstate malapportionment as measured with the VAP of each state persists — similar to the numbers displayed in the preceding paragraph (see Appendix Tables 1 through 5 for details). The maximum deviation in states' ideal VAPs with the current apportionment decreases by two-hundredths of a percent, to $65.33 \%$, of the national ideal district size. 
Reapportioning the House with the VAP data, however, would have decreased the maximum deviation percent to $57.47 \%$. As mentioned, the VAP is still not an entirely accurate enumeration of potential votes-though certainly closer to a literal interpretation than total population-because it includes noncitizens, felons, etc. The VEP measure is even closer to the literal interpretation of one person, one vote. And, the 2010 interstate malapportionment figures increase substantially if VEP is evaluated for each state and its current apportionment. In this case, the maximum deviation in states' ideal VEP jumps to $77.31 \%$ of the national ideal district size. Furthermore, given the state variations in population, eligibility, and the number of House districts, the 2010 apportionment provides each eligible voter in Rhode Island with just about twice the voting power of each eligible voter in Montana - the voter equivalency ratio. It is difficult to reconcile the current implementation of "one person, one vote" when these variations create foreseeable results in which "one Rhode Islander, two votes" vis-à-vis a Montanan.

Amending the Constitution to apportion on potential voters, either with the VAP or the VEP, would also have deep implications for reapportionment. Tables 4 through 8 provide the number of House seats that each state would receive in each reapportionment from 1970 to $2010^{8}$ as well as the number of seat changes among the three population measures: Apportionment Population $(A P) —$ which is currently used, VAP, and VEP ${ }^{9}$ (see Appendix Tables 6 through 10 for population details). Specifically, in 1970 if the U.S. House had been apportioned with VAP instead of AP, 10 House seats would have been changed: five states (CT, NJ, NY, OR, and PA) would have gained seats and five states (LA, MI, SC, SD, and TX) would have lost one seat. In 1980, there is a 6seat difference between AP and VAP, a 10-seat difference between $A P$ and VEP, and a 10-seat difference between VAP and VEP. Overall, the apportionment of 11 states is affected by which measure is used (AP, VAP, or VEP) to approximate the one person, one vote standard.

The question of which population standard to use becomes even more consequential starting with the 1990 reapportionment. For the 1990 reapportionment, there would have been 10 seat changes if VAP were used instead of AP, 18 seat changes if VEP would have been used instead of AP, and 18 seat changes if VEP would have been used instead of VAP. Overall, the population used affects the apportionment of 17 states. And, for the 2000 reapportionment, there would have been 6 seat changes if VAP were used instead of AP, 40

\footnotetext{
${ }^{8}$ The Hill Method of Equal Proportions was used to apportion the 435-seat U.S. House. See U.S. Code 2 Section $2 a$.

${ }^{9}$ The AP and VAP data are from the U.S. Census Bureau. The VEP data are from the Public Mapping Project (see www.publicmapping.org). Unfortunately, the Public Mapping Project does not have VEP for 1970.
}

seat changes if VEP were used instead of AP, and 36 seat changes if VEP would have been used instead of VAP. Finally, for the 2010 reapportionment, there would have been 10 seat changes if VAP were used instead of AP, 26 seat changes if VEP were used instead of AP, and 22 seat changes if VEP would have been used instead of VAP. Overall, the population standard used affects the apportionment across these decades for 34 states - and, some quite dramatically. For example, in 2000 California has a high of 53 seats (AP) and a low of 45 seats (VEP).

Changing the population used for the apportionment from, say, AP to VAP or VEP would arguably bring the practice of apportionment closer in line with the literal meaning of "one person, one vote". It also would have brought it numerically closer-though, there is no guarantee that this would persist for future apportionments. In 2010, if the VEP was used as the apportionment population (resulting in the district distribution found in Table 8), the interstate malapportionment measurement of the maximum deviation percent (the most commonly used statistic by the Supreme Court to assess intrastate malapportionment) in states' ideal VEP would drop to $55.20 \%$ of the national ideal district size (see Appendix Table 5 for details). Any change would also have numerous effects in the U.S. Congress and state politics. But, one of the most direct effects would be on the President through the Electoral College.

Table 9 displays the Electoral College vote as it was with the actual Apportionment Population from 1972 through 2012 and recalculates the vote if the House had been reapportioned with VAP or VEP. If VAP had been used, the vote would have changed in more than half of the eleven Presidential elections. Even though five of the six instances in which a vote change occurred, the same President would have been elected, the 2000 Presidential election would have ended in a 268 to 269 split. $^{10}$ This split gives neither Republican George W. Bush nor Democrat Al Gore an absolute majority of 270 Electoral College votes to win the Presidency. In this case, the 2000 presidential election would have been decided in the U.S. House of Representatives. If the VEP had been the population measure, then four of the eight presidential elections for which we have data would have witnessed a change in the Electoral College vote, but none of the outcomes - including the 2000 election - would have changed. Nonetheless, the U.S. House of Representatives and the Electoral College would arguably have more closely reflected the literal interpretation of the democratic norm enshrined in the constitutional principle of one person, one vote.

\footnotetext{
${ }^{10}$ Gore's count omits the faithless elector from Washington, D.C. who abstained from the actual 2000 Electoral College vote. However, given the VAP results, she probably would have cast her ballot-thereby giving Gore 269 Electoral Votes. Either way, the absolute majority of 270 votes would not have been garnered by either presidential candidate.
} 
Table 4. Apportionment in 1972 by Different Population Measures.

\begin{tabular}{|c|c|c|c|c|}
\hline State & $\begin{array}{r}\text { AP } \\
\text { Districts } \\
\end{array}$ & $\begin{array}{r}\text { VAP } \\
\text { Districts } \\
\end{array}$ & $\begin{array}{r}\text { Change } \\
\# 1 \\
\end{array}$ & $\begin{array}{r}\text { |Change } \\
\# 1 \mid \\
\end{array}$ \\
\hline Alabama & 7 & 7 & 0 & $\overline{0}$ \\
\hline Alaska & 1 & 1 & 0 & 0 \\
\hline Arizona & 4 & 4 & 0 & 0 \\
\hline Arkansas & 4 & 4 & 0 & 0 \\
\hline California & 43 & 43 & 0 & 0 \\
\hline Colorado & 5 & 5 & 0 & 0 \\
\hline Connecticut & 6 & 7 & 1 & 1 \\
\hline Delaware & 1 & 1 & 0 & 0 \\
\hline Florida & 15 & 15 & 0 & 0 \\
\hline Georgia & 10 & 10 & 0 & 0 \\
\hline Hawaii & 2 & 2 & 0 & 0 \\
\hline Idaho & 2 & 2 & 0 & 0 \\
\hline Illinois & 24 & 24 & 0 & 0 \\
\hline Indiana & 11 & 11 & 0 & 0 \\
\hline lowa & 6 & 6 & 0 & 0 \\
\hline Kansas & 5 & 5 & 0 & 0 \\
\hline Kentucky & 7 & 7 & 0 & 0 \\
\hline Louisiana & 8 & 7 & -1 & 1 \\
\hline Maine & 2 & 2 & 0 & 0 \\
\hline Maryland & 8 & 8 & 0 & 0 \\
\hline Massachusetts & 12 & 12 & 0 & 0 \\
\hline Michigan & 19 & 18 & -1 & 1 \\
\hline Minnesota & 8 & 8 & 0 & 0 \\
\hline Mississippi & 5 & 5 & 0 & 0 \\
\hline Missouri & 10 & 10 & 0 & 0 \\
\hline Montana & 2 & 2 & 0 & 0 \\
\hline Nebraska & 3 & 3 & 0 & 0 \\
\hline Nevada & 1 & 1 & 0 & 0 \\
\hline New Hampshire & 2 & 2 & 0 & 0 \\
\hline New Jersey & 15 & 16 & 1 & 1 \\
\hline New Mexico & 2 & 2 & 0 & 0 \\
\hline New York & 39 & 40 & 1 & 1 \\
\hline North Carolina & 11 & 11 & 0 & 0 \\
\hline North Dakota & 1 & 1 & 0 & 0 \\
\hline Ohio & 23 & 23 & 0 & 0 \\
\hline Oklahoma & 6 & 6 & 0 & 0 \\
\hline Oregon & 4 & 5 & 1 & 1 \\
\hline Pennsylvania & 25 & 26 & 1 & 1 \\
\hline Rhode Island & 2 & 2 & 0 & 0 \\
\hline South Carolina & 6 & 5 & -1 & 1 \\
\hline South Dakota & 2 & 1 & -1 & 1 \\
\hline Tennessee & 8 & 8 & 0 & 0 \\
\hline Texas & 24 & 23 & -1 & 1 \\
\hline Utah & 2 & 2 & 0 & 0 \\
\hline Vermont & 1 & 1 & 0 & 0 \\
\hline Virginia & 10 & 10 & 0 & 0 \\
\hline Washington & 7 & 7 & 0 & 0 \\
\hline West Virginia & 4 & 4 & 0 & 0 \\
\hline Wisconsin & 9 & 9 & 0 & 0 \\
\hline Wyoming & 1 & 1 & 0 & 0 \\
\hline Total & 435 & 435 & 0 & 10 \\
\hline
\end{tabular}

Note: shaded states experience a change in one of the three change measures. AP: Apportionment Population; VAP: Voting Age Population. 1. Change of VAP - AP. 
Table 5. Apportionment in 1982 by Different Population Measures.

\begin{tabular}{|c|c|c|c|c|c|c|c|c|c|}
\hline State & $\begin{array}{r}\text { AP } \\
\text { Districts }\end{array}$ & $\begin{array}{r}\text { VAP } \\
\text { Districts }\end{array}$ & $\begin{array}{r}\text { VEP } \\
\text { Districts }\end{array}$ & $\begin{array}{r}\text { Change } \\
\# 1\end{array}$ & $\begin{array}{r}\mid \text { Change } \\
\# 1 \mid\end{array}$ & $\begin{array}{r}\text { Change } \\
\# 2\end{array}$ & $\begin{array}{r}\mid \text { Change } \\
\# 2 \mid\end{array}$ & $\begin{array}{r}\text { Change } \\
\# 3\end{array}$ & $\begin{array}{r}\mid \text { Change } \\
\# 3 \mid\end{array}$ \\
\hline Alabama & 7 & 7 & 7 & 0 & 0 & 0 & 0 & 0 & 0 \\
\hline Alaska & 1 & 1 & 1 & 0 & 0 & 0 & 0 & 0 & 0 \\
\hline Arizona & 5 & 5 & 5 & 0 & 0 & 0 & 0 & 0 & 0 \\
\hline Arkansas & 4 & 4 & 4 & 0 & 0 & 0 & 0 & 0 & 0 \\
\hline California & 45 & 46 & 43 & 1 & 1 & -2 & 2 & -3 & 3 \\
\hline Colorado & 6 & 6 & 6 & 0 & 0 & 0 & 0 & 0 & 0 \\
\hline Connecticut & 6 & 6 & 6 & 0 & 0 & 0 & 0 & 0 & 0 \\
\hline Delaware & 1 & 1 & 1 & 0 & 0 & 0 & 0 & 0 & 0 \\
\hline Florida & 19 & 20 & 19 & 1 & 1 & 0 & 0 & -1 & 1 \\
\hline Georgia & 10 & 10 & 10 & 0 & 0 & 0 & 0 & 0 & 0 \\
\hline Hawaii & 2 & 2 & 2 & 0 & 0 & 0 & 0 & 0 & 0 \\
\hline Idaho & 2 & 2 & 2 & 0 & 0 & 0 & 0 & 0 & 0 \\
\hline Illinois & 22 & 22 & 22 & 0 & 0 & 0 & 0 & 0 & 0 \\
\hline Indiana & 10 & 10 & 11 & 0 & 0 & 1 & 1 & 1 & 1 \\
\hline lowa & 6 & 6 & 6 & 0 & 0 & 0 & 0 & 0 & 0 \\
\hline Kansas & 5 & 5 & 5 & 0 & 0 & 0 & 0 & 0 & 0 \\
\hline Kentucky & 7 & 7 & 7 & 0 & 0 & 0 & 0 & 0 & 0 \\
\hline Louisiana & 8 & 8 & 8 & 0 & 0 & 0 & 0 & 0 & 0 \\
\hline Maine & 2 & 2 & 2 & 0 & 0 & 0 & 0 & 0 & 0 \\
\hline Maryland & 8 & 8 & 8 & 0 & 0 & 0 & 0 & 0 & 0 \\
\hline Massachusetts & 11 & 11 & 11 & 0 & 0 & 0 & 0 & 0 & 0 \\
\hline Michigan & 18 & 17 & 18 & -1 & 1 & 0 & 0 & 1 & 1 \\
\hline Minnesota & 8 & 8 & 8 & 0 & 0 & 0 & 0 & 0 & 0 \\
\hline Mississippi & 5 & 5 & 5 & 0 & 0 & 0 & 0 & 0 & 0 \\
\hline Missouri & 9 & 10 & 10 & 1 & 1 & 1 & 1 & 0 & 0 \\
\hline Montana & 2 & 2 & 2 & 0 & 0 & 0 & 0 & 0 & 0 \\
\hline Nebraska & 3 & 3 & 3 & 0 & 0 & 0 & 0 & 0 & 0 \\
\hline Nevada & 2 & 2 & 2 & 0 & 0 & 0 & 0 & 0 & 0 \\
\hline New Hampshire & 2 & 2 & 2 & 0 & 0 & 0 & 0 & 0 & 0 \\
\hline New Jersey & 14 & 14 & 14 & 0 & 0 & 0 & 0 & 0 & 0 \\
\hline New Mexico & 3 & 2 & 2 & -1 & 1 & -1 & 1 & 0 & 0 \\
\hline New York & 34 & 34 & 33 & 0 & 0 & -1 & 1 & -1 & 1 \\
\hline North Carolina & 11 & 11 & 12 & 0 & 0 & 1 & 1 & 1 & 1 \\
\hline North Dakota & 1 & 1 & 1 & 0 & 0 & 0 & 0 & 0 & 0 \\
\hline Ohio & 21 & 21 & 21 & 0 & 0 & 0 & 0 & 0 & 0 \\
\hline Oklahoma & 6 & 6 & 6 & 0 & 0 & 0 & 0 & 0 & 0 \\
\hline Oregon & 5 & 5 & 5 & 0 & 0 & 0 & 0 & 0 & 0 \\
\hline Pennsylvania & 23 & 23 & 24 & 0 & 0 & 1 & 1 & 1 & 1 \\
\hline Rhode Island & 2 & 2 & 2 & 0 & 0 & 0 & 0 & 0 & 0 \\
\hline South Carolina & 6 & 6 & 6 & 0 & 0 & 0 & 0 & 0 & 0 \\
\hline South Dakota & 1 & 1 & 1 & 0 & 0 & 0 & 0 & 0 & 0 \\
\hline Tennessee & 9 & 9 & 9 & 0 & 0 & 0 & 0 & 0 & 0 \\
\hline Texas & 27 & 26 & 26 & -1 & 1 & -1 & 1 & 0 & 0 \\
\hline Utah & 3 & 3 & 3 & 0 & 0 & 0 & 0 & 0 & 0 \\
\hline Vermont & 1 & 1 & 1 & 0 & 0 & 0 & 0 & 0 & 0 \\
\hline Virginia & 10 & 10 & 11 & 0 & 0 & 1 & 1 & 1 & 1 \\
\hline Washington & 8 & 8 & 8 & 0 & 0 & 0 & 0 & 0 & 0 \\
\hline West Virginia & 4 & 4 & 4 & 0 & 0 & 0 & 0 & 0 & 0 \\
\hline Wisconsin & 9 & 9 & 9 & 0 & 0 & 0 & 0 & 0 & 0 \\
\hline Wyoming & 1 & 1 & 1 & 0 & 0 & 0 & 0 & 0 & 0 \\
\hline Totals & 435 & 435 & 435 & 0 & 6 & 0 & 10 & 0 & 10 \\
\hline
\end{tabular}

Note: Shaded states experience a change in one of the three change measures. AP: Apportionment Population; VAP: Voting Age Population; VEP: Voting Eligible Population. 1. Change of VAP - AP; 2. Change of VEP - AP; 3. Change of VEP - VAP. 
Table 6. Apportionment in 1992 by Different Population Measures.

\begin{tabular}{|c|c|c|c|c|c|c|c|c|c|}
\hline State & $\begin{array}{r}\mathrm{AP} \\
\text { Dictrictc }\end{array}$ & VAP & VEP & Change & |Change & Change & $\begin{array}{r}\mid \text { Change } \\
\# 2 \mid\end{array}$ & $\begin{array}{r}\text { Change } \\
\text {. }\end{array}$ & $\begin{array}{r}\mid \text { Change } \\
\# 3 \mid\end{array}$ \\
\hline Alabama & $\begin{array}{r}\text { Districts } \\
7\end{array}$ & $\begin{array}{r}\text { Districts } \\
7\end{array}$ & $\begin{array}{r}\text { Districts } \\
7\end{array}$ & $\begin{array}{r}\# 1 \\
0\end{array}$ & $\begin{array}{r}\# 1 \mid \\
0\end{array}$ & $\begin{array}{r}\# 2 \\
0\end{array}$ & $\begin{array}{r}\# 2 \mid \\
0\end{array}$ & $\begin{array}{r}\# 3 \\
0\end{array}$ & $\begin{array}{r}\# 3 \mid \\
0\end{array}$ \\
\hline Alaska & 1 & 1 & 1 & 0 & 0 & 0 & 0 & 0 & 0 \\
\hline Arizona & 6 & 6 & 6 & 0 & 0 & 0 & 0 & 0 & 0 \\
\hline Arkansas & 4 & 4 & 4 & 0 & 0 & 0 & 0 & 0 & 0 \\
\hline California & 52 & 52 & 45 & 0 & 0 & -7 & 7 & -7 & 7 \\
\hline Colorado & 6 & 6 & 6 & 0 & 0 & 0 & 0 & 0 & 0 \\
\hline Connecticut & 6 & 6 & 6 & 0 & 0 & 0 & 0 & 0 & 0 \\
\hline Delaware & 1 & 1 & 1 & 0 & 0 & 0 & 0 & 0 & 0 \\
\hline Florida & 23 & 24 & 23 & 1 & 1 & 0 & 0 & -1 & 1 \\
\hline Georgia & 11 & 11 & 12 & 0 & 0 & 1 & 1 & 1 & 1 \\
\hline Hawaii & 2 & 2 & 2 & 0 & 0 & 0 & 0 & 0 & 0 \\
\hline Idaho & 2 & 2 & 2 & 0 & 0 & 0 & 0 & 0 & 0 \\
\hline Illinois & 20 & 20 & 20 & 0 & 0 & 0 & 0 & 0 & 0 \\
\hline Indiana & 10 & 10 & 10 & 0 & 0 & 0 & 0 & 0 & 0 \\
\hline lowa & 5 & 5 & 5 & 0 & 0 & 0 & 0 & 0 & 0 \\
\hline Kansas & 4 & 4 & 4 & 0 & 0 & 0 & 0 & 0 & 0 \\
\hline Kentucky & 6 & 6 & 7 & 0 & 0 & 1 & 1 & 1 & 1 \\
\hline Louisiana & 7 & 7 & 7 & 0 & 0 & 0 & 0 & 0 & 0 \\
\hline Maine & 2 & 2 & 2 & 0 & 0 & 0 & 0 & 0 & 0 \\
\hline Maryland & 8 & 9 & 9 & 1 & 1 & 1 & 1 & 0 & 0 \\
\hline Massachusetts & 10 & 11 & 11 & 1 & 1 & 1 & 1 & 0 & 0 \\
\hline Michigan & 16 & 16 & 17 & 0 & 0 & 1 & 1 & 1 & 1 \\
\hline Minnesota & 8 & 8 & 8 & 0 & 0 & 0 & 0 & 0 & 0 \\
\hline Mississippi & 5 & 4 & 5 & -1 & 1 & 0 & 0 & 1 & 1 \\
\hline Missouri & 9 & 9 & 9 & 0 & 0 & 0 & 0 & 0 & 0 \\
\hline Montana & 1 & 1 & 2 & 0 & 0 & 1 & 1 & 1 & 1 \\
\hline Nebraska & 3 & 3 & 3 & 0 & 0 & 0 & 0 & 0 & 0 \\
\hline Nevada & 2 & 2 & 2 & 0 & 0 & 0 & 0 & 0 & 0 \\
\hline New Hampshire & 2 & 2 & 2 & 0 & 0 & 0 & 0 & 0 & 0 \\
\hline New Jersey & 13 & 14 & 14 & 1 & 1 & 1 & 1 & 0 & 0 \\
\hline New Mexico & 3 & 3 & 3 & 0 & 0 & 0 & 0 & 0 & 0 \\
\hline New York & 31 & 32 & 31 & 1 & 1 & 0 & 0 & -1 & 1 \\
\hline North Carolina & 12 & 12 & 12 & 0 & 0 & 0 & 0 & 0 & 0 \\
\hline North Dakota & 1 & 1 & 1 & 0 & 0 & 0 & 0 & 0 & 0 \\
\hline Ohio & 19 & 19 & 20 & 0 & 0 & 1 & 1 & 1 & 1 \\
\hline Oklahoma & 6 & 5 & 6 & -1 & 1 & 0 & 0 & 1 & 1 \\
\hline Oregon & 5 & 5 & 5 & 0 & 0 & 0 & 0 & 0 & 0 \\
\hline Pennsylvania & 21 & 21 & 22 & 0 & 0 & 1 & 1 & 1 & 1 \\
\hline Rhode Island & 2 & 2 & 2 & 0 & 0 & 0 & 0 & 0 & 0 \\
\hline South Carolina & 6 & 6 & 6 & 0 & 0 & 0 & 0 & 0 & 0 \\
\hline South Dakota & 1 & 1 & 1 & 0 & 0 & 0 & 0 & 0 & 0 \\
\hline Tennessee & 9 & 9 & 9 & 0 & 0 & 0 & 0 & 0 & 0 \\
\hline Texas & 30 & 29 & 28 & -1 & 1 & -2 & 2 & -1 & 1 \\
\hline Utah & 3 & 3 & 3 & 0 & 0 & 0 & 0 & 0 & 0 \\
\hline Vermont & 1 & 1 & 1 & 0 & 0 & 0 & 0 & 0 & 0 \\
\hline Virginia & 11 & 11 & 11 & 0 & 0 & 0 & 0 & 0 & 0 \\
\hline Washington & 9 & 8 & 9 & -1 & 1 & 0 & 0 & 1 & 1 \\
\hline West Virginia & 3 & 3 & 3 & 0 & 0 & 0 & 0 & 0 & 0 \\
\hline Wisconsin & 9 & 8 & 9 & -1 & 1 & 0 & 0 & 1 & 1 \\
\hline Wyoming & 1 & 1 & 1 & 0 & 0 & 0 & 0 & 0 & 0 \\
\hline Total & 435 & 435 & 435 & 0 & 10 & 0 & 18 & 0 & 18 \\
\hline
\end{tabular}

Note: shaded states experience a change in one of the three change measures. AP: Apportionment Population; VAP: Voting Age Population; VEP: Voting Eligible Population. 1. Change of VAP - AP; 2. Change of VEP - AP; 3. Change of VEP - VAP. 
Table 7. Apportionment in 2002 by Different Population Measures.

\begin{tabular}{|c|c|c|c|c|c|c|c|c|c|}
\hline State & $\begin{array}{r}\text { AP } \\
\text { Dictrictc }\end{array}$ & VAP & VEP & Change & |Change & Change & |Change & $\begin{array}{r}\text { Change } \\
\text {. }\end{array}$ & $\begin{array}{r}\mid \text { Change } \\
\# 3 \mid\end{array}$ \\
\hline Alabama & 7 & 7 & 7 & 0 & 0 & 0 & 0 & 0 & 0 \\
\hline Alaska & 1 & 1 & 1 & 0 & 0 & 0 & 0 & 0 & 0 \\
\hline Arizona & 8 & 8 & 6 & 0 & 0 & -2 & 2 & -2 & 2 \\
\hline Arkansas & 4 & 4 & 4 & 0 & 0 & 0 & 0 & 0 & 0 \\
\hline California & 53 & 51 & 45 & -2 & 2 & -8 & 8 & -6 & 6 \\
\hline Colorado & 7 & 7 & 6 & 0 & 0 & -1 & 1 & -1 & 1 \\
\hline Connecticut & 5 & 5 & 6 & 0 & 0 & 1 & 1 & 1 & 1 \\
\hline Delaware & 1 & 1 & 1 & 0 & 0 & 0 & 0 & 0 & 0 \\
\hline Florida & 25 & 26 & 23 & 1 & 1 & -2 & 2 & -3 & 3 \\
\hline Georgia & 13 & 13 & 12 & 0 & 0 & -1 & 1 & -1 & 1 \\
\hline Hawaii & 2 & 2 & 2 & 0 & 0 & 0 & 0 & 0 & 0 \\
\hline Idaho & 2 & 2 & 2 & 0 & 0 & 0 & 0 & 0 & 0 \\
\hline Illinois & 19 & 19 & 20 & 0 & 0 & 1 & 1 & 1 & 1 \\
\hline Indiana & 9 & 9 & 10 & 0 & 0 & 1 & 1 & 1 & 1 \\
\hline lowa & 5 & 5 & 5 & 0 & 0 & 0 & 0 & 0 & 0 \\
\hline Kansas & 4 & 4 & 4 & 0 & 0 & 0 & 0 & 0 & 0 \\
\hline Kentucky & 6 & 6 & 7 & 0 & 0 & 1 & 1 & 1 & 1 \\
\hline Louisiana & 7 & 7 & 7 & 0 & 0 & 0 & 0 & 0 & 0 \\
\hline Maine & 2 & 2 & 2 & 0 & 0 & 0 & 0 & 0 & 0 \\
\hline Maryland & 8 & 8 & 9 & 0 & 0 & 1 & 1 & 1 & 1 \\
\hline Massachusetts & 10 & 10 & 11 & 0 & 0 & 1 & 1 & 1 & 1 \\
\hline Michigan & 15 & 15 & 17 & 0 & 0 & 2 & 2 & 2 & 2 \\
\hline Minnesota & 8 & 8 & 8 & 0 & 0 & 0 & 0 & 0 & 0 \\
\hline Mississippi & 4 & 4 & 5 & 0 & 0 & 1 & 1 & 1 & 1 \\
\hline Missouri & 9 & 9 & 9 & 0 & 0 & 0 & 0 & 0 & 0 \\
\hline Montana & 1 & 1 & 2 & 0 & 0 & 1 & 1 & 1 & 1 \\
\hline Nebraska & 3 & 3 & 3 & 0 & 0 & 0 & 0 & 0 & 0 \\
\hline Nevada & 3 & 3 & 2 & 0 & 0 & -1 & 1 & -1 & 1 \\
\hline New Hampshire & 2 & 2 & 2 & 0 & 0 & 0 & 0 & 0 & 0 \\
\hline New Jersey & 13 & 13 & 14 & 0 & 0 & 1 & 1 & 1 & 1 \\
\hline New Mexico & 3 & 3 & 3 & 0 & 0 & 0 & 0 & 0 & 0 \\
\hline New York & 29 & 30 & 31 & 1 & 1 & 2 & 2 & 1 & 1 \\
\hline North Carolina & 13 & 13 & 12 & 0 & 0 & -1 & 1 & -1 & 1 \\
\hline North Dakota & 1 & 1 & 1 & 0 & 0 & 0 & 0 & 0 & 0 \\
\hline Ohio & 18 & 18 & 20 & 0 & 0 & 2 & 2 & 2 & 2 \\
\hline Oklahoma & 5 & 5 & 6 & 0 & 0 & 1 & 1 & 1 & 1 \\
\hline Oregon & 5 & 5 & 5 & 0 & 0 & 0 & 0 & 0 & 0 \\
\hline Pennsylvania & 19 & 20 & 22 & 1 & 1 & 3 & 3 & 2 & 2 \\
\hline Rhode Island & 2 & 2 & 2 & 0 & 0 & 0 & 0 & 0 & 0 \\
\hline South Carolina & 6 & 6 & 6 & 0 & 0 & 0 & 0 & 0 & 0 \\
\hline South Dakota & 1 & 1 & 1 & 0 & 0 & 0 & 0 & 0 & 0 \\
\hline Tennessee & 9 & 9 & 9 & 0 & 0 & 0 & 0 & 0 & 0 \\
\hline Texas & 32 & 31 & 28 & -1 & 1 & -4 & 4 & -3 & 3 \\
\hline Utah & 3 & 3 & 3 & 0 & 0 & 0 & 0 & 0 & 0 \\
\hline Vermont & 1 & 1 & 1 & 0 & 0 & 0 & 0 & 0 & 0 \\
\hline Virginia & 11 & 11 & 11 & 0 & 0 & 0 & 0 & 0 & 0 \\
\hline Washington & 9 & 9 & 9 & 0 & 0 & 0 & 0 & 0 & 0 \\
\hline West Virginia & 3 & 3 & 3 & 0 & 0 & 0 & 0 & 0 & 0 \\
\hline Wisconsin & 8 & 8 & 9 & 0 & 0 & 1 & 1 & 1 & 1 \\
\hline Wyoming & 1 & 1 & 1 & 0 & 0 & 0 & 0 & 0 & 0 \\
\hline Total & 435 & 435 & 435 & 0 & 6 & 0 & 40 & 0 & 36 \\
\hline
\end{tabular}

Note: shaded states experience a change in one of the three change measures. AP: Apportionment Population; VAP: Voting Age Population; VEP: Voting Eligible Population. 1. Change of VAP - AP; 2. Change of VEP - AP; 3. Change of VEP - VAP. 
Table 8. Apportionment in the 2012 by Different Population Measures.

\begin{tabular}{|c|c|c|c|c|c|c|c|c|c|}
\hline State & $\begin{array}{r}A P \\
\text { Districts }\end{array}$ & $\begin{array}{r}\text { VAP } \\
\text { Districts }\end{array}$ & $\begin{array}{r}\text { VEP } \\
\text { Districts }\end{array}$ & $\begin{array}{r}\text { Change } \\
\# 1 \\
\end{array}$ & $\begin{array}{r}\mid \text { Change } \\
\# 1 \mid\end{array}$ & $\begin{array}{r}\text { Change } \\
\# 2 \\
\end{array}$ & $\begin{array}{r}\text { Change } \\
\# 2 \mid \\
\end{array}$ & $\begin{array}{r}\text { Change } \\
\# 3 \\
\end{array}$ & $\begin{array}{r}\mid \text { Change } \\
\# 3 \mid \\
\end{array}$ \\
\hline Alabama & 7 & 7 & 7 & 0 & 0 & 0 & 0 & 0 & 0 \\
\hline Alaska & 1 & 1 & 1 & 0 & 0 & 0 & 0 & 0 & 0 \\
\hline Arizona & 9 & 9 & 9 & 0 & 0 & 0 & 0 & 0 & 0 \\
\hline Arkansas & 4 & 4 & 4 & 0 & 0 & 0 & 0 & 0 & 0 \\
\hline California & 53 & 52 & 47 & -1 & 1 & -6 & 6 & -5 & 5 \\
\hline Colorado & 7 & 7 & 7 & 0 & 0 & 0 & 0 & 0 & 0 \\
\hline Connecticut & 5 & 5 & 5 & 0 & 0 & 0 & 0 & 0 & 0 \\
\hline Delaware & 1 & 1 & 1 & 0 & 0 & 0 & 0 & 0 & 0 \\
\hline Florida & 27 & 27 & 26 & 0 & 0 & -1 & 1 & -1 & 1 \\
\hline Georgia & 14 & 13 & 13 & -1 & 1 & -1 & 1 & 0 & 0 \\
\hline Hawaii & 2 & 2 & 2 & 0 & 0 & 0 & 0 & 0 & 0 \\
\hline Idaho & 2 & 2 & 2 & 0 & 0 & 0 & 0 & 0 & 0 \\
\hline Illinois & 18 & 18 & 18 & 0 & 0 & 0 & 0 & 0 & 0 \\
\hline Indiana & 9 & 9 & 10 & 0 & 0 & 1 & 1 & 1 & 1 \\
\hline lowa & 4 & 4 & 5 & 0 & 0 & 1 & 1 & 1 & 1 \\
\hline Kansas & 4 & 4 & 4 & 0 & 0 & 0 & 0 & 0 & 0 \\
\hline Kentucky & 6 & 6 & 7 & 0 & 0 & 1 & 1 & 1 & 1 \\
\hline Louisiana & 6 & 6 & 7 & 0 & 0 & 1 & 1 & 1 & 1 \\
\hline Maine & 2 & 2 & 2 & 0 & 0 & 0 & 0 & 0 & 0 \\
\hline Maryland & 8 & 8 & 8 & 0 & 0 & 0 & 0 & 0 & 0 \\
\hline Massachusetts & 9 & 10 & 10 & 1 & 1 & 1 & 1 & 0 & 0 \\
\hline Michigan & 14 & 14 & 15 & 0 & 0 & 1 & 1 & 1 & 1 \\
\hline Minnesota & 8 & 7 & 8 & -1 & 1 & 0 & 0 & 1 & 1 \\
\hline Mississippi & 4 & 4 & 4 & 0 & 0 & 0 & 0 & 0 & 0 \\
\hline Missouri & 8 & 8 & 9 & 0 & 0 & 1 & 1 & 1 & 1 \\
\hline Montana & 1 & 2 & 2 & 1 & 1 & 1 & 1 & 0 & 0 \\
\hline Nebraska & 3 & 3 & 3 & 0 & 0 & 0 & 0 & 0 & 0 \\
\hline Nevada & 4 & 4 & 4 & 0 & 0 & 0 & 0 & 0 & 0 \\
\hline New Hampshire & 2 & 2 & 2 & 0 & 0 & 0 & 0 & 0 & 0 \\
\hline New Jersey & 12 & 13 & 12 & 1 & 1 & 0 & 0 & -1 & 1 \\
\hline New Mexico & 3 & 3 & 3 & 0 & 0 & 0 & 0 & 0 & 0 \\
\hline New York & 27 & 28 & 27 & 1 & 1 & 0 & 0 & -1 & 1 \\
\hline North Carolina & 13 & 13 & 14 & 0 & 0 & 1 & 1 & 1 & 1 \\
\hline North Dakota & 1 & 1 & 1 & 0 & 0 & 0 & 0 & 0 & 0 \\
\hline Ohio & 16 & 16 & 17 & 0 & 0 & 1 & 1 & 1 & 1 \\
\hline Oklahoma & 5 & 5 & 5 & 0 & 0 & 0 & 0 & 0 & 0 \\
\hline Oregon & 5 & 6 & 6 & 1 & 1 & 1 & 1 & 0 & 0 \\
\hline Pennsylvania & 18 & 18 & 19 & 0 & 0 & 1 & 1 & 1 & 1 \\
\hline Rhode Island & 2 & 2 & 2 & 0 & 0 & 0 & 0 & 0 & 0 \\
\hline South Carolina & 7 & 7 & 7 & 0 & 0 & 0 & 0 & 0 & 0 \\
\hline South Dakota & 1 & 1 & 1 & 0 & 0 & 0 & 0 & 0 & 0 \\
\hline Tennessee & 9 & 9 & 9 & 0 & 0 & 0 & 0 & 0 & 0 \\
\hline Texas & 36 & 34 & 31 & -2 & 2 & -5 & 5 & -3 & 3 \\
\hline Utah & 4 & 4 & 4 & 0 & 0 & 0 & 0 & 0 & 0 \\
\hline Vermont & 1 & 1 & 1 & 0 & 0 & 0 & 0 & 0 & 0 \\
\hline Virginia & 11 & 11 & 12 & 0 & 0 & 1 & 1 & 1 & 1 \\
\hline Washington & 10 & 10 & 10 & 0 & 0 & 0 & 0 & 0 & 0 \\
\hline West Virginia & 3 & 3 & 3 & 0 & 0 & 0 & 0 & 0 & 0 \\
\hline Wisconsin & 8 & 8 & 8 & 0 & 0 & 0 & 0 & 0 & 0 \\
\hline Wyoming & 1 & 1 & 1 & 0 & 0 & 0 & 0 & 0 & 0 \\
\hline Total & 435 & 435 & 435 & 0 & 10 & 0 & 26 & 0 & 22 \\
\hline
\end{tabular}

Note: shaded states experience a change in one of the three change measures. AP: Apportionment Population; VAP: Voting Age Population; VEP: Voting Eligible Population. 1. Change of VAP - AP; 2. Change of VEP - AP; 3. Change of VEP - VAP. 
Table 9. The Electoral College Vote Based on Three Different Measures of Reapportioned State Population, $1972-2008$.

\begin{tabular}{|c|c|c|c|c|c|c|c|c|c|c|c|}
\hline Measure & 1972 & 1976 & 1980 & 1984 & 1988 & 1992 & 1996 & 2000 & 2004 & 2008 & 2012 \\
\hline \multicolumn{12}{|c|}{ Apportioned Population } \\
\hline Democratic Votes & 17 & 297 & 49 & 13 & 111 & 370 & 379 & 266 & 251 & 365 & 332 \\
\hline Republican Votes & 520 & 240 & 489 & 525 & 426 & 168 & 159 & 271 & 286 & 173 & 206 \\
\hline Winner & $\mathrm{R}$ & D & $\mathrm{R}$ & $\mathrm{R}$ & $\mathrm{R}$ & D & D & $\mathrm{R}$ & $\mathrm{R}$ & $\mathrm{D}$ & $\mathrm{D}$ \\
\hline \multicolumn{12}{|c|}{ Voting Age Population } \\
\hline Democratic Votes & 17 & 296 & 49 & 13 & 111 & 372 & 382 & 268 & 251 & 366 & 334 \\
\hline Republican Votes & 520 & 241 & 489 & 525 & 426 & 166 & 156 & 269 & 286 & 172 & 204 \\
\hline Winner & $\mathrm{R}$ & D & $\mathrm{R}$ & $\mathrm{R}$ & $\mathrm{R}$ & D & D & Neither & $\mathrm{R}$ & $\mathrm{D}$ & D \\
\hline \multicolumn{12}{|c|}{ Voting Eligible Population } \\
\hline Democratic Votes & -- & -- & -- & 13 & 111 & 372 & 379 & 264 & 256 & 368 & 332 \\
\hline Republican Votes & -- & -- & -- & 525 & 426 & 166 & 159 & 273 & 281 & 170 & 206 \\
\hline Winner & -- & -- & -- & $\mathrm{R}$ & $\mathrm{R}$ & D & D & $\mathrm{R}$ & $\mathrm{R}$ & $\mathrm{D}$ & D \\
\hline
\end{tabular}

Note: Data on Electoral Vote returns from 1972-2004 are from CQ's Guide to U.S. Elections (2005) and the 2008 returns are from Dave Leip's Atlas of U.S. Presidential Elections (uselectionatlas.org/RESULTS/). Shaded vote returns indicate a different distribution or result than the official returns based on the apportioned population. According to a reapportionment based on the VAP, in 2000 there would not have been an outright winner since both Bush and Gore would not have secured a 270-vote majority. Hence, the 2000 contest would have been decided in the U.S. House of Representatives.

\section{Conclusion}

In this study we have taken empirical inventory of the one person, one vote principle in congressional reapportionment and redistricting. The established legal precedent for intrastate redistricting relies on minimizing deviations away from a measure of total population. To be sure, in states with multiple districts, they now exhibit hardly any deviation from the equal total population standard. But the current equal total population standard is not the only possible one. Instead, other standards are possible, and some of these (such as VAP or VEP) arguably more closely reflect the literal interpretation of the democratic norm and constitutional principle of "one-person, one-vote". We have also shown that the current use of total population and its intrastate equalization has not led concomitantly to similar equalizations in the variance of voting age populations (VAPs). This is an important finding in and of itself. The Court should be clear in what it means by its continued usage of the "one-person, one-vote" principle. The different measures that are employed and can be inferred from the principle are far from commensurate.

In addition to finding that intrastate deviations in the VAP have not been systematically reduced in recent congressional redistrictings, we also demonstrate that measures of state populations that are more closely aligned with actual voters would considerably alter decennial reapportionments. For instance, if we were to reallocate U.S. House seats on the basis of the VAP or the VEP, two measures that afford actual voters a more "equally weighted" vote, then there would be substantial changes in the redistribution of congressional districts. Further, the differences in seat allocations based on the different population standards have grown in more recent cycles because many of the high population growth states contain demographic groups with lower citizenship rates and lower VAPs (e.g., Hispanic growth in Arizona and Texas). This means that certain slow growth northern states (e.g., New Jersey and Pennsylvania) with higher VAPs and VEPs are shortchanged congressional representation according to these alternative standards.

We have also shown that in several presidential elections the two-party Electoral College vote totals would be somewhat altered if House seats were reallocated according to an alternative standard, such as VAP or VEP. And since the high growth states are generally located in the Sun Belt where the GOP is stronger but the resident populations are disproportionately younger, ${ }^{11}$ the redistribution of congressional districts according to the VAP and VEP would likely advantage - at least in the near term - the Democratic Party since it is electorally stronger in low growth northern states. In fact, if the 2000 presidential election results were based on a congressional reapportionment tied to state voting age population, then neither party would have won an Electoral College majority - meaning the next president would have been determined by the U.S. House of Representatives.

\footnotetext{
${ }^{11}$ California is the exception to this rule, a "blue" state with a significantly lower voting eligible population.
} 
Our findings in this study make it clear that the current apportionment and redistricting standard based on total population, whether at the district- or statelevel, is but just one possible standard. Furthermore, we argue that the definition of "total population" has not been constant, complete, or consistent between the two processes. As such, other definitions and standards are possible, and they may even be more consistent with some of our democratic principles. As importantly, these other definitions and standards produce different results - that is, the interpretation and explanations of the Court matter significantly in practical terms. As for any potential standard closer to a literal interpretation of one person, one vote, the Census only now is beginning to provide the requisite data to analyze the consequences of such a change.

To be sure, however, any population standard will leave us well short in one manner or another of meeting such a lofty and perhaps impractical principle. For example, even though the Court has made tremendous progress in basically eliminating intrastate malapportionment among U.S. House districts, this equalization is largely limited to one defined standard of one person, one vote. Assessing the "equalized" districts on other logical and credible standards demonstrates much less equality, and thus, leaves a backdoor open that could allow line drawers considerable leeway to manipulate maps for partisan gain (Winburn, 2008). As such, in a matter as central to our democracy as the equality of the vote, more reliable and precise data as well as much more scholarship and jurisprudence are necessary to more fully understand this debate - much less resolve it.

\section{Acknowledgements}

An early rendition of this paper was presented at the 2012 State Politics and Policy Conference, and we thank our discussants Richard Murray and Jon Winburn for their helpful feedback. We also appreciate the advice and suggestions from our anonymous reviewers because it greatly improved the final version of the article.

\section{Conflicts of Interest}

The authors declare no conflicts of interest in conducting this research.

\section{References}

Anderson, M. J. (1988). The American Census: A Social History. New Haven, CT: Yale University Press.

Ansolabehere, S., \& Snyder, J. (2008). The End of Inequality: One Person, One Vote and the Transformation of American Politics. New York, USA: W.W. Norton.
Ansolabehere, S., Gerber, A., \& Snyder, J. (2002). Equal Votes, Equal Money: Court-Ordered Redistricting and Public Expenditures in the American States. American Political Science Review, 96(4), 767-777.

Balinski, ML, Young, HP. (2001). Fair Representation: Meeting the Ideal of One Man, One Vote. Washington, DC: Brookings Institution Press.

Black, E., \& Black, M. (2002). The Rise of Southern Republicans. Cambridge, MA, USA: Harvard University Press.

Bullock, C. S. (2010). Redistricting: The Most Political Activity in America. Lanham, MD, USA: Rowman \& Littlefield.

Bullock, C. S., \& Gaddie, R. K. (2009). The Triumph of Voting Rights in the South. Norman, OK, USA: University of Oklahoma Press.

Butler, K. I. (2002). Redistricting in a Post-Shaw Era: A Small Treatise Accompanied by Districting Guidelines for Legislators, Litigants, and Courts. University of Richmond Law Review, 36(1), 137-270.

Cox, G., \& Katz, J. N. (2002). Elbridge Gerry's Salamander: The Electoral Consequences of the Reapportionment Revolution. Cambridge, UK: Cambridge University Press.

Davidson C. (Ed.). (1984). Minority Vote Dilution. Washington, DC, USA: Howard University Press.

Desposato, S. W., \& Petrocik, J. R. (2003). The Variable Incumbency Advantage: New Voters, Redistricting, and the Personal Vote. American Journal of Political Science, 47(1), 18-32.

Epstein, D., \& O'Halloran, S. (1999). Measuring the Electoral and Policy Impact of Majority-Minority Voting Districts. American Journal of Political Science, 43(2), 367-395.

Fenno, R. F. (1978). Home Style: House Members in their Districts. Boston, USA: Little.

Fishkin J. (2012). Weightless Votes. The Yale Law Journal, 121(7), 1888-1910.

Hill, K. A. (1995). Does the Creation of Majority Black Districts Aid Republicans? An Analysis of the 1992 Congressional Elections in Eight Southern States. Journal of Politics, 57(2), 384-401.

Key, V. O. (1949). Southern Politics in State and Nation. New York, USA: Alfred A. Knopf.

Ladewig, J. W. (2011). One Person, One Vote, 435 Seats: Interstate Malapportionment and Constitutional Requirements. University of Connecticut Law Review, 43(4), 1127-1156.

Ladewig, J. W., \& Jasinski, M. P. (2008). On the Causes and Consequences of and Remedies for Interstate Malapportionment of the U.S. House of Representatives. Perspectives on Politics, 6(1), 89-107.

Levinson, S. (1985). Gerrymandering and the Brooding Omnipresence of Proportional Representation: Why Won't It Go Away? UCLA Law Review, 33(1), 257-281. 
Levinson, S. (2002). One Person, One Vote: A Mantra in Need of Meaning. North Carolina Law Review, 80(4), 1269-1297.

Lublin, D. (1997). The Paradox of Representation: Racial Gerrymandering and Minority Interests in Congress. Princeton, NJ, USA: Princeton University Press.

McKee, S. C. (2004). Review Essay: The Impact of Congressional Redistricting in the 1990s on Minority Representation, Party Competition, and Legislative Responsiveness. Journal of Political Science, 32(1), 146.

McKee, S. C. (2008). The Effects of Redistricting on Voting Behavior in Incumbent U.S. House Elections, 19921994. Political Research Quarterly, 61(1), 122-133.

McKee, S. C., \& Shaw, D. R. (2005). Redistricting in Texas: Institutionalizing Republican Ascendancy. In P. F. Galderisi (Ed.), Redistricting in the New Millennium. Lanham, MD, USA: Lexington Books.

Mills, K. M. (1993). Americans Overseas in U.S. Censuses, Technical Paper no. 62. Bureau of the Census: U.S. Department of Commerce.
Parker, F. R. (1990). Black Votes Count: Political Empowerment in Mississippi after 1965. Chapel Hill, NC, USA: University of North Carolina Press.

Persily, N. (2011). The Law of the Census: How to Count, What to Count, Whom to Count, and Where to Count Them. Cardozo Law Review, 32(3), 755789.

Petrocik, J. R., \& Desposato, S. W. (1998). The Partisan Consequences of Majority-Minority Redistricting in the South, 1992 and 1994. Journal of Politics, 60(3), 613-633.

Public Mapping Project. Retrieved from www.public mapping.org

Shotts, K. (2001). The Effect of Majority-Minority Mandates on Partisan Gerrymandering. American Journal of Political Science, 45(1), 120-135.

Winburn, J. (2008). The Realities of Redistricting: Following the Rules and Limiting Gerrymandering in State Legislative Redistricting. Lanham, MD, USA: Lexington Books.

\section{About the Authors}
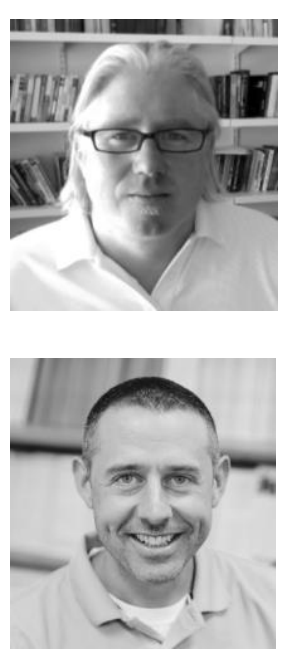

\section{Dr. Jeffrey W. Ladewig}

Jeffrey Ladewig earned his Ph.D. from the Department of Government at the University of Texas at Austin in 2002 and his B.A. from the Department of Political Science and the Department of Economics from the University of Wisconsin at Madison in 1993. His primary areas of research include developing political economy models of party and ideological polarization in the U.S. Congress, the effects of income inequality in the U.S, and congressional apportionment. He has also published research on the organization of Congress, public opinion and voting behavior, as well as international political economy.

\section{Dr. Seth C. McKee}

Seth C. McKee received his Ph.D. in Government from the University of Texas in 2005, a Masters degree in Economics (1998), and a Bachelors degree in Political Science (1996) from Oklahoma State University. His primary area of research focuses on American electoral politics and especially party system change in the American South. He has published research on such topics as political participation, vote choice, redistricting, party switching, and strategic voting behavior. McKee is the author of Republican Ascendancy in Southern U.S. House Elections (Westview Press 2010). 


\section{Appendixes}

Appendix Table 1. 2012 Interstate Malapportionment: AP Districts and AP Population.

\begin{tabular}{|c|c|c|c|c|c|c|}
\hline State & $\begin{array}{r}\text { Apportionment } \\
\text { Population }\end{array}$ & $\begin{array}{r}\text { Number of } \\
\text { MCs }\end{array}$ & $\begin{array}{r}\text { State Ideal Dis- } \\
\text { trict Size }\end{array}$ & $\begin{array}{r}\text { Deviation from } \\
\text { Ideal }\end{array}$ & $\begin{array}{l}\text { Absolute Devia- } \\
\text { tion from Ideal }\end{array}$ & $\begin{array}{r}\% \text { Deviation } \\
\text { form Ideal }\end{array}$ \\
\hline Alabama & $4,779,736$ & 7 & 682,819 & 25,557 & 25,557 & $3.61 \%$ \\
\hline Alaska & 710,231 & 1 & 710,231 & $-1,854$ & 1,854 & $-0.26 \%$ \\
\hline Arizona & $6,392,017$ & 9 & 710,224 & $-1,848$ & 1,848 & $-0.26 \%$ \\
\hline Arkansas & $2,915,918$ & 4 & 728,980 & $-20,603$ & 20,603 & $-2.91 \%$ \\
\hline California & $37,253,956$ & 53 & 702,905 & 5,472 & 5,472 & $0.77 \%$ \\
\hline Colorado & $5,029,196$ & 7 & 718,457 & $-10,080$ & 10,080 & $-1.42 \%$ \\
\hline Connecticut & $3,574,097$ & 5 & 714,819 & $-6,443$ & 6,443 & $-0.91 \%$ \\
\hline Delaware & 897,934 & 1 & 897,934 & $-189,557$ & 189,557 & $-26.76 \%$ \\
\hline Florida & $18,801,310$ & 27 & 696,345 & 12,032 & 12,032 & $1.70 \%$ \\
\hline Georgia & $9,687,653$ & 14 & 691,975 & 16,401 & 16,401 & $2.32 \%$ \\
\hline Hawaii & $1,360,301$ & 2 & 680,151 & 28,226 & 28,226 & $3.98 \%$ \\
\hline Idaho & $1,567,582$ & 2 & 783,791 & $-75,414$ & 75,414 & $-10.65 \%$ \\
\hline Illinois & $12,830,632$ & 18 & 712,813 & $-4,436$ & 4,436 & $-0.63 \%$ \\
\hline Indiana & $6,483,802$ & 9 & 720,422 & $-12,046$ & 12,046 & $-1.70 \%$ \\
\hline lowa & $3,046,355$ & 4 & 761,589 & $-53,212$ & 53,212 & $-7.51 \%$ \\
\hline Kansas & $2,853,118$ & 4 & 713,280 & $-4,903$ & 4,903 & $-0.69 \%$ \\
\hline Kentucky & $4,339,367$ & 6 & 723,228 & $-14,851$ & 14,851 & $-2.10 \%$ \\
\hline Louisiana & $4,533,372$ & 6 & 755,562 & $-47,185$ & 47,185 & $-6.66 \%$ \\
\hline Maine & $1,328,361$ & 2 & 664,181 & 44,196 & 44,196 & $6.24 \%$ \\
\hline Maryland & $5,773,552$ & 8 & 721,694 & $-13,317$ & 13,317 & $-1.88 \%$ \\
\hline Massachusetts & $6,547,629$ & 9 & 727,514 & $-19,138$ & 19,138 & $-2.70 \%$ \\
\hline Michigan & $9,883,640$ & 14 & 705,974 & 2,402 & 2,402 & $0.34 \%$ \\
\hline Minnesota & $5,303,925$ & 8 & 662,991 & 45,386 & 45,386 & $6.41 \%$ \\
\hline Mississippi & $2,967,297$ & 4 & 741,824 & $-33,448$ & 33,448 & $-4.72 \%$ \\
\hline Missouri & $5,988,927$ & 8 & 748,616 & $-40,239$ & 40,239 & $-5.68 \%$ \\
\hline Montana & 989,415 & 1 & 989,415 & $-281,038$ & 281,038 & $-39.67 \%$ \\
\hline Nebraska & $1,826,341$ & 3 & 608,780 & 99,596 & 99,596 & $14.06 \%$ \\
\hline Nevada & $2,700,551$ & 4 & 675,138 & 33,239 & 33,239 & $4.69 \%$ \\
\hline New Hampshire & $1,316,470$ & 2 & 658,235 & 50,142 & 50,142 & $7.08 \%$ \\
\hline New Jersey & $8,791,894$ & 12 & 732,658 & $-24,281$ & 24,281 & $-3.43 \%$ \\
\hline New Mexico & $2,059,179$ & 3 & 686,393 & 21,984 & 21,984 & $3.10 \%$ \\
\hline New York & $19,378,102$ & 27 & 717,707 & $-9,331$ & 9,331 & $-1.32 \%$ \\
\hline North Carolina & $9,535,483$ & 13 & 733,499 & $-25,122$ & 25,122 & $-3.55 \%$ \\
\hline North Dakota & 672,591 & 1 & 672,591 & 35,786 & 35,786 & $5.05 \%$ \\
\hline Ohio & $11,536,504$ & 16 & 721,032 & $-12,655$ & 12,655 & $-1.79 \%$ \\
\hline Oklahoma & $3,751,351$ & 5 & 750,270 & $-41,894$ & 41,894 & $-5.91 \%$ \\
\hline Oregon & $3,831,074$ & 5 & 766,215 & $-57,838$ & 57,838 & $-8.16 \%$ \\
\hline Pennsylvania & $12,702,379$ & 18 & 705,688 & 2,689 & 2,689 & $0.38 \%$ \\
\hline Rhode Island & $1,052,567$ & 2 & 526,284 & 182,093 & 182,093 & $25.71 \%$ \\
\hline South Carolina & $4,625,364$ & 7 & 660,766 & 47,610 & 47,610 & $6.72 \%$ \\
\hline South Dakota & 814,180 & 1 & 814,180 & $-105,803$ & 105,803 & $-14.94 \%$ \\
\hline Tennessee & $6,346,105$ & 9 & 705,123 & 3,254 & 3,254 & $0.46 \%$ \\
\hline Texas & $25,145,561$ & 36 & 698,488 & 9,889 & 9,889 & $1.40 \%$ \\
\hline Utah & $2,763,885$ & 4 & 690,971 & 17,405 & 17,405 & $2.46 \%$ \\
\hline Vermont & 625,741 & 1 & 625,741 & 82,636 & 82,636 & $11.67 \%$ \\
\hline Virginia & $8,001,024$ & 11 & 727,366 & $-18,989$ & 18,989 & $-2.68 \%$ \\
\hline Washington & $6,724,540$ & 10 & 672,454 & 35,923 & 35,923 & $5.07 \%$ \\
\hline West Virginia & $1,852,994$ & 3 & 617,665 & 90,712 & 90,712 & $12.81 \%$ \\
\hline Wisconsin & $5,686,986$ & 8 & 710,873 & $-2,497$ & 2,497 & $-0.35 \%$ \\
\hline Wyoming & 563,626 & 1 & 563,626 & 144,751 & 144,751 & $20.43 \%$ \\
\hline
\end{tabular}


Appendix Table 1. Cont.

\begin{tabular}{|c|c|c|c|c|c|c|}
\hline State & $\begin{array}{r}\text { Apportionment } \\
\text { Population }\end{array}$ & $\begin{array}{r}\text { Number of } \\
\text { MCs }\end{array}$ & $\begin{array}{l}\text { State Ideal } \\
\text { District Size }\end{array}$ & $\begin{array}{r}\text { Deviation from } \\
\text { Ideal }\end{array}$ & $\begin{array}{l}\text { Absolute Devia- } \\
\text { tion from Ideal }\end{array}$ & $\begin{array}{r}\text { \% Deviation } \\
\text { form Ideal }\end{array}$ \\
\hline Totals & $308,143,815$ & 435 & 708,377 & & & \\
\hline Voter Equivalency Ratio & & & 1.88 & & & \\
\hline Most Underrepresented & & & & $-281,038$ & & $-39.67 \%$ \\
\hline Most Overrepresented & & & & 182,093 & & $25.71 \%$ \\
\hline Maximum Deviation & & & & 463,132 & & \\
\hline$\%$ Max Deviation & & & & & & $65.38 \%$ \\
\hline Mean Absolute Deviation & & & & & 43,308 & \\
\hline$\%$ Mean Abs Deviation & & & & & & $6.11 \%$ \\
\hline
\end{tabular}

Appendix Table 2. 2012 Interstate Malapportionment: AP Districts and VAP Population.

\begin{tabular}{|c|c|c|c|c|c|c|}
\hline State & $\begin{array}{l}\text { Apportionment } \\
\text { Population }\end{array}$ & $\begin{array}{r}\text { Number of } \\
\text { MCs }\end{array}$ & $\begin{array}{l}\text { State Ideal } \\
\text { District Size }\end{array}$ & $\begin{array}{l}\text { Deviation } \\
\text { from Ideal }\end{array}$ & $\begin{array}{l}\text { Absolute Devia- } \\
\text { tion from Ideal }\end{array}$ & $\begin{array}{r}\% \text { Deviation } \\
\text { form Ideal }\end{array}$ \\
\hline Alabama & $3,647,277$ & 7 & 521,040 & 17,037 & 17,037 & $3.17 \%$ \\
\hline Alaska & 522,853 & 1 & 522,853 & 15,223 & 15,223 & $2.83 \%$ \\
\hline Arizona & $4,763,003$ & 9 & 529,223 & 8,854 & 8,854 & $1.65 \%$ \\
\hline Arkansas & $2,204,443$ & 4 & 551,111 & $-13,035$ & 13,035 & $-2.42 \%$ \\
\hline California & $27,958,916$ & 53 & 527,527 & 10,550 & 10,550 & $1.96 \%$ \\
\hline Colorado & $3,803,587$ & 7 & 543,370 & $-5,293$ & 5,293 & $-0.98 \%$ \\
\hline Connecticut & $2,757,082$ & 5 & 551,416 & $-13,340$ & 13,340 & $-2.48 \%$ \\
\hline Delaware & 692,169 & 1 & 692,169 & $-154,093$ & 154,093 & $-28.64 \%$ \\
\hline Florida & $14,799,219$ & 27 & 548,119 & $-10,043$ & 10,043 & $-1.87 \%$ \\
\hline Georgia & $7,196,101$ & 14 & 514,007 & 24,069 & 24,069 & $4.47 \%$ \\
\hline Hawaii & $1,056,483$ & 2 & 528,242 & 9,835 & 9,835 & $1.83 \%$ \\
\hline Idaho & $1,138,510$ & 2 & 569,255 & $-31,179$ & 31,179 & $-5.79 \%$ \\
\hline Illinois & $9,701,453$ & 18 & 538,970 & -893 & 893 & $-0.17 \%$ \\
\hline Indiana & $4,875,504$ & 9 & 541,723 & $-3,646$ & 3,646 & $-0.68 \%$ \\
\hline lowa & $2,318,362$ & 4 & 579,591 & $-41,514$ & 41,514 & $-7.72 \%$ \\
\hline Kansas & $2,126,179$ & 4 & 531,545 & 6,531 & 6,531 & $1.21 \%$ \\
\hline Kentucky & $3,315,996$ & 6 & 552,666 & $-14,590$ & 14,590 & $-2.71 \%$ \\
\hline Louisiana & $3,415,357$ & 6 & 569,226 & $-31,150$ & 31,150 & $-5.79 \%$ \\
\hline Maine & $1,053,828$ & 2 & 526,914 & 11,162 & 11,162 & $2.07 \%$ \\
\hline Maryland & $4,420,588$ & 8 & 552,574 & $-14,497$ & 14,497 & $-2.69 \%$ \\
\hline Massachusetts & $5,128,706$ & 9 & 569,856 & $-31,780$ & 31,780 & $-5.91 \%$ \\
\hline Michigan & $7,539,572$ & 14 & 538,541 & -465 & 465 & $-0.09 \%$ \\
\hline Minnesota & $4,019,862$ & 8 & 502,483 & 35,593 & 35,593 & $6.61 \%$ \\
\hline Mississippi & $2,211,742$ & 4 & 552,936 & $-14,859$ & 14,859 & $-2.76 \%$ \\
\hline Missouri & $4,563,491$ & 8 & 570,436 & $-32,360$ & 32,360 & $-6.01 \%$ \\
\hline Montana & 765,852 & 1 & 765,852 & $-227,776$ & 227,776 & $-42.33 \%$ \\
\hline Nebraska & $1,367,120$ & 3 & 455,707 & 82,370 & 82,370 & $15.31 \%$ \\
\hline Nevada & $2,035,543$ & 4 & 508,886 & 29,190 & 29,190 & $5.42 \%$ \\
\hline New Hampshire & $1,029,236$ & 2 & 514,618 & 23,458 & 23,458 & $4.36 \%$ \\
\hline New Jersey & $6,726,680$ & 12 & 560,557 & $-22,480$ & 22,480 & $-4.18 \%$ \\
\hline New Mexico & $1,540,507$ & 3 & 513,502 & 24,574 & 24,574 & $4.57 \%$ \\
\hline New York & $15,053,173$ & 27 & 557,525 & $-19,449$ & 19,449 & $-3.61 \%$ \\
\hline North Carolina & $7,253,848$ & 13 & 557,988 & $-19,912$ & 19,912 & $-3.70 \%$ \\
\hline North Dakota & 522,720 & 1 & 522,720 & 15,356 & 15,356 & $2.85 \%$ \\
\hline Ohio & $8,805,753$ & 16 & 550,360 & $-12,283$ & 12,283 & $-2.28 \%$ \\
\hline Oklahoma & $2,821,685$ & 5 & 564,337 & $-26,261$ & 26,261 & $-4.88 \%$ \\
\hline Oregon & $2,964,621$ & 5 & 592,924 & $-54,848$ & 54,848 & $-10.19 \%$ \\
\hline Pennsylvania & $9,910,224$ & 18 & 550,568 & $-12,492$ & 12,492 & $-2.32 \%$ \\
\hline Rhode Island & 828,611 & 2 & 414,306 & 123,771 & 123,771 & $23.00 \%$ \\
\hline
\end{tabular}


Appendix Table 2. Cont.

\begin{tabular}{|c|c|c|c|c|c|c|}
\hline State & $\begin{array}{l}\text { Apportionment } \\
\text { Population }\end{array}$ & $\begin{array}{r}\text { Number of } \\
\text { MCs }\end{array}$ & $\begin{array}{r}\text { State Ideal } \\
\text { District Size }\end{array}$ & $\begin{array}{l}\text { Deviation } \\
\text { from Ideal }\end{array}$ & $\begin{array}{l}\text { Absolute Devia- } \\
\text { tion from Ideal }\end{array}$ & $\begin{array}{r}\% \text { Deviation } \\
\text { form Ideal }\end{array}$ \\
\hline South Carolina & $3,544,890$ & 7 & 506,413 & 31,663 & 31,663 & $5.88 \%$ \\
\hline South Dakota & 611,383 & 1 & 611,383 & $-73,307$ & 73,307 & $-13.62 \%$ \\
\hline Tennessee & $4,850,104$ & 9 & 538,900 & -824 & 824 & $-0.15 \%$ \\
\hline Texas & $18,279,737$ & 36 & 507,770 & 30,306 & 30,306 & $5.63 \%$ \\
\hline Utah & $1,892,858$ & 4 & 473,215 & 64,862 & 64,862 & $12.05 \%$ \\
\hline Vermont & 496,508 & 1 & 496,508 & 41,568 & 41,568 & $7.73 \%$ \\
\hline Virginia & $6,147,347$ & 11 & 558,850 & $-20,773$ & 20,773 & $-3.86 \%$ \\
\hline Washington & $5,143,186$ & 10 & 514,319 & 23,758 & 23,758 & $4.42 \%$ \\
\hline West Virginia & $1,465,576$ & 3 & 488,525 & 49,551 & 49,551 & $9.21 \%$ \\
\hline Wisconsin & $4,347,494$ & 8 & 543,437 & $-5,361$ & 5,361 & $-1.00 \%$ \\
\hline Wyoming & 428,224 & 1 & 428,224 & 109,852 & 109,852 & $20.42 \%$ \\
\hline Totals & $234,063,163$ & 435 & 538,076 & & & \\
\hline Voter Equivalency Ratio & & & 1.85 & & & \\
\hline Most Underrepresented & & & & $-227,776$ & & $-42.33 \%$ \\
\hline Most Overrepresented & & & & 123,771 & & $23.00 \%$ \\
\hline Maximum Deviation & & & & 351,547 & & \\
\hline$\%$ Max Deviation & & & & & & $65.33 \%$ \\
\hline Mean Absolute Deviation & & & & & 33,953 & \\
\hline$\%$ Mean Abs Deviation & & & & & & $6.31 \%$ \\
\hline
\end{tabular}

Appendix Table 3. 2012 Interstate Malapportionment: AP Districts and VEP Population.

\begin{tabular}{|c|c|c|c|c|c|c|}
\hline State & $\begin{array}{r}\text { Apportionment } \\
\text { Population }\end{array}$ & $\begin{array}{r}\text { Number of } \\
M C s\end{array}$ & $\begin{array}{l}\text { State Ideal } \\
\text { District Size }\end{array}$ & $\begin{array}{l}\text { Deviation } \\
\text { from Ideal }\end{array}$ & $\begin{array}{l}\text { Absolute Devia- } \\
\text { tion from Ideal }\end{array}$ & $\begin{array}{r}\text { \% Deviation } \\
\text { form Ideal }\end{array}$ \\
\hline Alabama & $3,472,784$ & 7 & 496,112 & $-7,958$ & 7,958 & $-1.63 \%$ \\
\hline Alaska & 492,159 & 1 & 492,159 & $-4,005$ & 4,005 & $-0.82 \%$ \\
\hline Arizona & $4,220,784$ & 9 & 468,976 & 19,178 & 19,178 & $3.93 \%$ \\
\hline Arkansas & $2,081,031$ & 4 & 520,258 & $-32,104$ & 32,104 & $-6.58 \%$ \\
\hline California & $22,921,454$ & 53 & 432,480 & 55,673 & 55,673 & $11.40 \%$ \\
\hline Colorado & $3,529,590$ & 7 & 504,227 & $-16,074$ & 16,074 & $-3.29 \%$ \\
\hline Connecticut & $2,514,825$ & 5 & 502,965 & $-14,811$ & 14,811 & $-3.03 \%$ \\
\hline Delaware & 648,840 & 1 & 648,840 & $-160,686$ & 160,686 & $-32.92 \%$ \\
\hline Florida & $12,939,596$ & 27 & 479,244 & 8,909 & 8,909 & $1.83 \%$ \\
\hline Georgia & $6,464,406$ & 14 & 461,743 & 26,410 & 26,410 & $5.41 \%$ \\
\hline Hawaii & 960,041 & 2 & 480,021 & 8,133 & 8,133 & $1.67 \%$ \\
\hline Idaho & $1,071,526$ & 2 & 535,763 & $-47,609$ & 47,609 & $-9.75 \%$ \\
\hline Illinois & $8,788,929$ & 18 & 488,274 & -120 & 120 & $-0.02 \%$ \\
\hline Indiana & $4,698,660$ & 9 & 522,073 & $-33,920$ & 33,920 & $-6.95 \%$ \\
\hline lowa & $2,232,917$ & 4 & 558,229 & $-70,076$ & 70,076 & $-14.36 \%$ \\
\hline Kansas & $2,009,563$ & 4 & 502,391 & $-14,237$ & 14,237 & $-2.92 \%$ \\
\hline Kentucky & $3,198,138$ & 6 & 533,023 & $-44,869$ & 44,869 & $-9.19 \%$ \\
\hline Louisiana & $3,246,213$ & 6 & 541,036 & $-52,882$ & 52,882 & $-10.83 \%$ \\
\hline Maine & $1,038,335$ & 2 & 519,168 & $-31,014$ & 31,014 & $-6.35 \%$ \\
\hline Maryland & $3,999,682$ & 8 & 499,960 & $-11,807$ & 11,807 & $-2.42 \%$ \\
\hline Massachusetts & $4,681,091$ & 9 & 520,121 & $-31,968$ & 31,968 & $-6.55 \%$ \\
\hline Michigan & $7,248,403$ & 14 & 517,743 & $-29,590$ & 29,590 & $-6.06 \%$ \\
\hline Minnesota & $3,803,802$ & 8 & 475,475 & 12,678 & 12,678 & $2.60 \%$ \\
\hline Mississippi & $2,131,049$ & 4 & 532,762 & $-44,609$ & 44,609 & $-9.14 \%$ \\
\hline Missouri & $4,365,737$ & 8 & 545,717 & $-57,564$ & 57,564 & $-11.79 \%$ \\
\hline Montana & 758,805 & 1 & 758,805 & $-270,651$ & 270,651 & $-55.44 \%$ \\
\hline Nebraska & $1,305,876$ & 3 & 435,292 & 52,862 & 52,862 & $10.83 \%$ \\
\hline Nevada & $1,750,950$ & 4 & 437,738 & 50,416 & 50,416 & $10.33 \%$ \\
\hline
\end{tabular}


Appendix Table 3. Cont.

\begin{tabular}{|c|c|c|c|c|c|c|}
\hline State & $\begin{array}{r}\text { Apportionment } \\
\text { Population }\end{array}$ & $\begin{array}{r}\text { Number of } \\
M C s\end{array}$ & $\begin{array}{r}\text { State Ideal } \\
\text { District Size }\end{array}$ & $\begin{array}{l}\text { Deviation } \\
\text { from Ideal }\end{array}$ & $\begin{array}{l}\text { Absolute Devia- } \\
\text { tion from Ideal }\end{array}$ & $\begin{array}{r}\% \text { Deviation } \\
\text { form Ideal }\end{array}$ \\
\hline New Hampshire & $1,000,167$ & 2 & 500,084 & $-11,930$ & 11,930 & $-2.44 \%$ \\
\hline New Jersey & $5,819,152$ & 12 & 484,929 & 3,224 & 3,224 & $0.66 \%$ \\
\hline New Mexico & $1,407,025$ & 3 & 469,008 & 19,145 & 19,145 & $3.92 \%$ \\
\hline New York & $13,121,745$ & 27 & 485,991 & 2,163 & 2,163 & $0.44 \%$ \\
\hline North Carolina & $6,791,748$ & 13 & 522,442 & $-34,289$ & 34,289 & $-7.02 \%$ \\
\hline North Dakota & 517,347 & 1 & 517,347 & $-29,193$ & 29,193 & $-5.98 \%$ \\
\hline Ohio & $8,568,112$ & 16 & 535,507 & $-47,353$ & 47,353 & $-9.70 \%$ \\
\hline Oklahoma & $2,669,051$ & 5 & 533,810 & $-45,657$ & 45,657 & $-9.35 \%$ \\
\hline Oregon & $2,762,313$ & 5 & 552,463 & $-64,309$ & 64,309 & $-13.17 \%$ \\
\hline Pennsylvania & $9,567,164$ & 18 & 531,509 & $-43,356$ & 43,356 & $-8.88 \%$ \\
\hline Rhode Island & 762,810 & 2 & 381,405 & 106,749 & 106,749 & $21.87 \%$ \\
\hline South Carolina & $3,387,826$ & 7 & 483,975 & 4,178 & 4,178 & $0.86 \%$ \\
\hline South Dakota & 599,838 & 1 & 599,838 & $-111,684$ & 111,684 & $-22.88 \%$ \\
\hline Tennessee & $4,621,221$ & 9 & 513,469 & $-25,315$ & 25,315 & $-5.19 \%$ \\
\hline Texas & $15,492,550$ & 36 & 430,349 & 57,805 & 57,805 & $11.84 \%$ \\
\hline Utah & $1,776,843$ & 4 & 444,211 & 43,943 & 43,943 & $9.00 \%$ \\
\hline Vermont & 489,123 & 1 & 489,123 & -969 & 969 & $-0.20 \%$ \\
\hline Virginia & $5,658,358$ & 11 & 514,396 & $-26,243$ & 26,243 & $-5.38 \%$ \\
\hline Washington & $4,724,989$ & 10 & 472,499 & 15,655 & 15,655 & $3.21 \%$ \\
\hline West Virginia & $1,442,796$ & 3 & 480,932 & 7,222 & 7,222 & $1.48 \%$ \\
\hline Wisconsin & $4,174,726$ & 8 & 521,841 & $-33,687$ & 33,687 & $-6.90 \%$ \\
\hline Wyoming & 416,693 & 1 & 416,693 & 71,461 & 71,461 & $14.64 \%$ \\
\hline Totals & $212,346,783$ & 435 & 488,154 & & & \\
\hline Voter Equivalency Ratio & & & 1.99 & & & \\
\hline Most Underrepresented & & & & $-270,651$ & & $-55.44 \%$ \\
\hline Most Overrepresented & & & & 106,749 & & $21.87 \%$ \\
\hline Maximum Deviation & & & & 377,400 & & \\
\hline \% Max Deviation & & & & & & $77.31 \%$ \\
\hline Mean Absolute Deviation & & & & & 40,327 & \\
\hline$\%$ Mean Abs Deviation & & & & & & $8.26 \%$ \\
\hline
\end{tabular}

Appendix Table 4. 2012 Interstate Malapportionment: VAP Districts and VAP Population.

\begin{tabular}{|c|c|c|c|c|c|c|}
\hline State & VAP & $\begin{array}{r}\text { Number of } \\
\text { MCs }\end{array}$ & $\begin{array}{r}\text { State Ideal } \\
\text { District Size }\end{array}$ & $\begin{array}{l}\text { Deviation } \\
\text { from Ideal }\end{array}$ & $\begin{array}{l}\text { Absolute Devia- } \\
\text { tion from Ideal }\end{array}$ & $\begin{array}{r}\% \text { Deviation } \\
\text { form Ideal }\end{array}$ \\
\hline Alabama & $3,647,277$ & 7 & 521,040 & 17,037 & 17,037 & $3.17 \%$ \\
\hline Alaska & 522,853 & 1 & 522,853 & 15,223 & 15,223 & $2.83 \%$ \\
\hline Arizona & $4,763,003$ & 9 & 529,223 & 8,854 & 8,854 & $1.65 \%$ \\
\hline Arkansas & $2,204,443$ & 4 & 551,111 & $-13,035$ & 13,035 & $-2.42 \%$ \\
\hline California & $27,958,916$ & 52 & 537,671 & 405 & 405 & $0.08 \%$ \\
\hline Colorado & $3,803,587$ & 7 & 543,370 & $-5,293$ & 5,293 & $-0.98 \%$ \\
\hline Connecticut & $2,757,082$ & 5 & 551,416 & $-13,340$ & 13,340 & $-2.48 \%$ \\
\hline Delaware & 692,169 & 1 & 692,169 & $-154,093$ & 154,093 & $-28.64 \%$ \\
\hline Florida & $14,799,219$ & 27 & 548,119 & $-10,043$ & 10,043 & $-1.87 \%$ \\
\hline Georgia & $7,196,101$ & 13 & 553,546 & $-15,470$ & 15,470 & $-2.88 \%$ \\
\hline Hawaii & $1,056,483$ & 2 & 528,242 & 9,835 & 9,835 & $1.83 \%$ \\
\hline Idaho & $1,138,510$ & 2 & 569,255 & $-31,179$ & 31,179 & $-5.79 \%$ \\
\hline Illinois & $9,701,453$ & 18 & 538,970 & -893 & 893 & $-0.17 \%$ \\
\hline Indiana & $4,875,504$ & 9 & 541,723 & $-3,646$ & 3,646 & $-0.68 \%$ \\
\hline lowa & $2,318,362$ & 4 & 579,591 & $-41,514$ & 41,514 & $-7.72 \%$ \\
\hline Kansas & $2,126,179$ & 4 & 531,545 & 6,531 & 6,531 & $1.21 \%$ \\
\hline Kentucky & $3,315,996$ & 6 & 552,666 & $-14,590$ & 14,590 & $-2.71 \%$ \\
\hline
\end{tabular}


Appendix Table 4. Cont.

\begin{tabular}{|c|c|c|c|c|c|c|}
\hline State & VAP & $\begin{array}{r}\text { Number of } \\
\text { MCs }\end{array}$ & $\begin{array}{l}\text { State Ideal } \\
\text { District Size }\end{array}$ & $\begin{array}{l}\text { Deviation } \\
\text { from Ideal }\end{array}$ & $\begin{array}{l}\text { Absolute Devia- } \\
\text { tion from Ideal }\end{array}$ & $\begin{array}{r}\text { \% Deviation } \\
\text { form Ideal }\end{array}$ \\
\hline Louisiana & $3,415,357$ & 6 & 569,226 & $-31,150$ & 31,150 & $-5.79 \%$ \\
\hline Maine & $1,053,828$ & 2 & 526,914 & 11,162 & 11,162 & $2.07 \%$ \\
\hline Maryland & $4,420,588$ & 8 & 552,574 & $-14,497$ & 14,497 & $-2.69 \%$ \\
\hline Massachusetts & $5,128,706$ & 10 & 512,871 & 25,206 & 25,206 & $4.68 \%$ \\
\hline Michigan & $7,539,572$ & 14 & 538,541 & -465 & 465 & $-0.09 \%$ \\
\hline Minnesota & $4,019,862$ & 7 & 574,266 & $-36,190$ & 36,190 & $-6.73 \%$ \\
\hline Mississippi & $2,211,742$ & 4 & 552,936 & $-14,859$ & 14,859 & $-2.76 \%$ \\
\hline Missouri & $4,563,491$ & 8 & 570,436 & $-32,360$ & 32,360 & $-6.01 \%$ \\
\hline Montana & 765,852 & 2 & 382,926 & 155,150 & 155,150 & $28.83 \%$ \\
\hline Nebraska & $1,367,120$ & 3 & 455,707 & 82,370 & 82,370 & $15.31 \%$ \\
\hline Nevada & $2,035,543$ & 4 & 508,886 & 29,190 & 29,190 & $5.42 \%$ \\
\hline New Hampshire & $1,029,236$ & 2 & 514,618 & 23,458 & 23,458 & $4.36 \%$ \\
\hline New Jersey & $6,726,680$ & 13 & 517,437 & 20,639 & 20,639 & $3.84 \%$ \\
\hline New Mexico & $1,540,507$ & 3 & 513,502 & 24,574 & 24,574 & $4.57 \%$ \\
\hline New York & $15,053,173$ & 28 & 537,613 & 463 & 463 & $0.09 \%$ \\
\hline North Carolina & $7,253,848$ & 13 & 557,988 & $-19,912$ & 19,912 & $-3.70 \%$ \\
\hline North Dakota & 522,720 & 1 & 522,720 & 15,356 & 15,356 & $2.85 \%$ \\
\hline Ohio & $8,805,753$ & 16 & 550,360 & $-12,283$ & 12,283 & $-2.28 \%$ \\
\hline Oklahoma & $2,821,685$ & 5 & 564,337 & $-26,261$ & 26,261 & $-4.88 \%$ \\
\hline Oregon & $2,964,621$ & 6 & 494,104 & 43,973 & 43,973 & $8.17 \%$ \\
\hline Pennsylvania & $9,910,224$ & 18 & 550,568 & $-12,492$ & 12,492 & $-2.32 \%$ \\
\hline Rhode Island & 828,611 & 2 & 414,306 & 123,771 & 123,771 & $23.00 \%$ \\
\hline South Carolina & $3,544,890$ & 7 & 506,413 & 31,663 & 31,663 & $5.88 \%$ \\
\hline South Dakota & 611,383 & 1 & 611,383 & $-73,307$ & 73,307 & $-13.62 \%$ \\
\hline Tennessee & $4,850,104$ & 9 & 538,900 & -824 & 824 & $-0.15 \%$ \\
\hline Texas & $18,279,737$ & 34 & 537,639 & 437 & 437 & $0.08 \%$ \\
\hline Utah & $1,892,858$ & 4 & 473,215 & 64,862 & 64,862 & $12.05 \%$ \\
\hline Vermont & 496,508 & 1 & 496,508 & 41,568 & 41,568 & $7.73 \%$ \\
\hline Virginia & $6,147,347$ & 11 & 558,850 & $-20,773$ & 20,773 & $-3.86 \%$ \\
\hline Washington & $5,143,186$ & 10 & 514,319 & 23,758 & 23,758 & $4.42 \%$ \\
\hline West Virginia & $1,465,576$ & 3 & 488,525 & 49,551 & 49,551 & $9.21 \%$ \\
\hline Wisconsin & $4,347,494$ & 8 & 543,437 & $-5,361$ & 5,361 & $-1.00 \%$ \\
\hline Wyoming & 428,224 & 1 & 428,224 & 109,852 & 109,852 & $20.42 \%$ \\
\hline Totals & $234,063,163$ & 435 & 538,076 & & & \\
\hline Voter Equivalency Ratio & & & 1.81 & & & \\
\hline Most Underrepresented & & & & $-154,093$ & & $-28.64 \%$ \\
\hline Most Overrepresented & & & & 155,150 & & $28.83 \%$ \\
\hline Maximum Deviation & & & & 309,243 & & \\
\hline \% Max Deviation & & & & & & $57.47 \%$ \\
\hline Mean Absolute Deviation & & & & & 30,774 & \\
\hline \% Mean Abs Deviation & & & & & & $5.72 \%$ \\
\hline
\end{tabular}

Appendix Table 5. 2012 Interstate Malapportionment: VEP Districts and VEP Population.

\begin{tabular}{|c|c|c|c|c|c|c|}
\hline State & VEP & $\begin{array}{r}\text { Number of } \\
\text { MCs }\end{array}$ & $\begin{array}{l}\text { State Ideal } \\
\text { District Size }\end{array}$ & $\begin{array}{l}\text { Deviation } \\
\text { from Ideal }\end{array}$ & $\begin{array}{l}\text { Absolute Devia- } \\
\text { tion from Ideal }\end{array}$ & $\begin{array}{r}\% \text { Deviation } \\
\text { form Ideal }\end{array}$ \\
\hline Alabama & $3,472,784$ & 7 & 496,112 & $-7,958$ & 7,958 & $-1.63 \%$ \\
\hline Alaska & 492,159 & 1 & 492,159 & $-4,005$ & 4,005 & $-0.82 \%$ \\
\hline Arizona & $4,220,784$ & 9 & 468,976 & 19,178 & 19,178 & $3.93 \%$ \\
\hline Arkansas & $2,081,031$ & 4 & 520,258 & $-32,104$ & 32,104 & $-6.58 \%$ \\
\hline California & $22,921,454$ & 47 & 487,691 & 463 & 463 & $0.09 \%$ \\
\hline Colorado & $3,529,590$ & 7 & 504,227 & $-16,074$ & 16,074 & $-3.29 \%$ \\
\hline
\end{tabular}


Appendix Table 5. Cont.

\begin{tabular}{|c|c|c|c|c|c|c|}
\hline State & VEP & $\begin{array}{r}\text { Number of } \\
\text { MCs }\end{array}$ & $\begin{array}{l}\text { State Ideal } \\
\text { District Size }\end{array}$ & $\begin{array}{l}\text { Deviation } \\
\text { from Ideal }\end{array}$ & $\begin{array}{l}\text { Absolute Devia- } \\
\text { tion from Ideal }\end{array}$ & $\begin{array}{r}\% \text { Deviation } \\
\text { form Ideal }\end{array}$ \\
\hline Connecticut & $2,514,825$ & 5 & 502,965 & $-14,811$ & 14,811 & $-3.03 \%$ \\
\hline Delaware & 648,840 & 1 & 648,840 & $-160,686$ & 160,686 & $-32.92 \%$ \\
\hline Florida & $12,939,596$ & 26 & 497,677 & $-9,523$ & 9,523 & $-1.95 \%$ \\
\hline Georgia & $6,464,406$ & 13 & 497,262 & $-9,108$ & 9,108 & $-1.87 \%$ \\
\hline Hawaii & 960,041 & 2 & 480,021 & 8,133 & 8,133 & $1.67 \%$ \\
\hline Idaho & $1,071,526$ & 2 & 535,763 & $-47,609$ & 47,609 & $-9.75 \%$ \\
\hline Illinois & $8,788,929$ & 18 & 488,274 & -120 & 120 & $-0.02 \%$ \\
\hline Indiana & $4,698,660$ & 10 & 469,866 & 18,288 & 18,288 & $3.75 \%$ \\
\hline lowa & $2,232,917$ & 5 & 446,583 & 41,570 & 41,570 & $8.52 \%$ \\
\hline Kansas & $2,009,563$ & 4 & 502,391 & $-14,237$ & 14,237 & $-2.92 \%$ \\
\hline Kentucky & $3,198,138$ & 7 & 456,877 & 31,277 & 31,277 & $6.41 \%$ \\
\hline Louisiana & $3,246,213$ & 7 & 463,745 & 24,409 & 24,409 & $5.00 \%$ \\
\hline Maine & $1,038,335$ & 2 & 519,168 & $-31,014$ & 31,014 & $-6.35 \%$ \\
\hline Maryland & $3,999,682$ & 8 & 499,960 & $-11,807$ & 11,807 & $-2.42 \%$ \\
\hline Massachusetts & $4,681,091$ & 10 & 468,109 & 20,044 & 20,044 & $4.11 \%$ \\
\hline Michigan & $7,248,403$ & 15 & 483,227 & 4,927 & 4,927 & $1.01 \%$ \\
\hline Minnesota & $3,803,802$ & 8 & 475,475 & 12,678 & 12,678 & $2.60 \%$ \\
\hline Mississippi & $2,131,049$ & 4 & 532,762 & $-44,609$ & 44,609 & $-9.14 \%$ \\
\hline Missouri & $4,365,737$ & 9 & 485,082 & 3,072 & 3,072 & $0.63 \%$ \\
\hline Montana & 758,805 & 2 & 379,403 & 108,751 & 108,751 & $22.28 \%$ \\
\hline Nebraska & $1,305,876$ & 3 & 435,292 & 52,862 & 52,862 & $10.83 \%$ \\
\hline Nevada & $1,750,950$ & 4 & 437,738 & 50,416 & 50,416 & $10.33 \%$ \\
\hline New Hampshire & $1,000,167$ & 2 & 500,084 & $-11,930$ & 11,930 & $-2.44 \%$ \\
\hline New Jersey & $5,819,152$ & 12 & 484,929 & 3,224 & 3,224 & $0.66 \%$ \\
\hline New Mexico & $1,407,025$ & 3 & 469,008 & 19,145 & 19,145 & $3.92 \%$ \\
\hline New York & $13,121,745$ & 27 & 485,991 & 2,163 & 2,163 & $0.44 \%$ \\
\hline North Carolina & $6,791,748$ & 14 & 485,125 & 3,029 & 3,029 & $0.62 \%$ \\
\hline North Dakota & 517,347 & 1 & 517,347 & $-29,193$ & 29,193 & $-5.98 \%$ \\
\hline Ohio & $8,568,112$ & 17 & 504,007 & $-15,853$ & 15,853 & $-3.25 \%$ \\
\hline Oklahoma & $2,669,051$ & 5 & 533,810 & $-45,657$ & 45,657 & $-9.35 \%$ \\
\hline Oregon & $2,762,313$ & 6 & 460,386 & 27,768 & 27,768 & $5.69 \%$ \\
\hline Pennsylvania & $9,567,164$ & 19 & 503,535 & $-15,381$ & 15,381 & $-3.15 \%$ \\
\hline Rhode Island & 762,810 & 2 & 381,405 & 106,749 & 106,749 & $21.87 \%$ \\
\hline South Carolina & $3,387,826$ & 7 & 483,975 & 4,178 & 4,178 & $0.86 \%$ \\
\hline South Dakota & 599,838 & 1 & 599,838 & $-111,684$ & 111,684 & $-22.88 \%$ \\
\hline Tennessee & $4,621,221$ & 9 & 513,469 & $-25,315$ & 25,315 & $-5.19 \%$ \\
\hline Texas & $15,492,550$ & 31 & 499,760 & $-11,606$ & 11,606 & $-2.38 \%$ \\
\hline Utah & $1,776,843$ & 4 & 444,211 & 43,943 & 43,943 & $9.00 \%$ \\
\hline Vermont & 489,123 & 1 & 489,123 & -969 & 969 & $-0.20 \%$ \\
\hline Virginia & $5,658,358$ & 12 & 471,530 & 16,624 & 16,624 & $3.41 \%$ \\
\hline Washington & $4,724,989$ & 10 & 472,499 & 15,655 & 15,655 & $3.21 \%$ \\
\hline West Virginia & $1,442,796$ & 3 & 480,932 & 7,222 & 7,222 & $1.48 \%$ \\
\hline Wisconsin & $4,174,726$ & 8 & 521,841 & $-33,687$ & 33,687 & $-6.90 \%$ \\
\hline Wyoming & 416,693 & 1 & 416,693 & 71,461 & 71,461 & $14.64 \%$ \\
\hline Totals & $212,346,783$ & 435 & 488,154 & & & \\
\hline Voter Equivalency Ratio & & & 1.71 & & & \\
\hline Most Underrepresented & & & & $-160,686$ & & $-32.92 \%$ \\
\hline Most Overrepresented & & & & 108,751 & & $22.28 \%$ \\
\hline Maximum Deviation & & & & 269,438 & & \\
\hline \% Max Deviation & & & & & & $55.20 \%$ \\
\hline Mean Absolute Deviation & & & & & 28,443 & \\
\hline$\%$ Mean Abs Deviation & & & & & & $5.83 \%$ \\
\hline
\end{tabular}


Appendix Table 6. Apportionment Populations in 1970

\begin{tabular}{|c|c|c|c|c|c|}
\hline State & AP & VAP & State & AP & VAP \\
\hline Alabama & $3,475,885$ & $2,205,486$ & Montana & 701,573 & 440,583 \\
\hline Alaska & 304,067 & 180,582 & Nebraska & $1,496,820$ & 973,236 \\
\hline Arizona & $1,787,620$ & $1,123,322$ & Nevada & 492,396 & 318,151 \\
\hline Arkansas & $1,942,303$ & $1,264,709$ & New Hampshire & 746,284 & 482,655 \\
\hline California & $20,098,863$ & $13,300,316$ & New Jersey & $7,208,035$ & $4,777,221$ \\
\hline Colorado & $2,226,771$ & $1,429,241$ & New Mexico & $1,026,664$ & 607,575 \\
\hline Connecticut & $3,050,693$ & $2,007,601$ & New York & $18,338,055$ & $12,368,821$ \\
\hline Delaware & 551,928 & 350,952 & North Carolina & $5,125,230$ & $3,312,968$ \\
\hline Florida & $6,855,702$ & $4,671,090$ & North Dakota & 624,181 & 390,141 \\
\hline Georgia & $4,627,306$ & $2,938,518$ & Ohio & $10,730,200$ & $6,902,333$ \\
\hline Hawaii & 784,901 & 492,986 & Oklahoma & $2,585,486$ & $1,718,812$ \\
\hline Idaho & 719,921 & 447,806 & Oregon & $2,110,810$ & $1,391,451$ \\
\hline Illinois & $11,184,320$ & $7,303,995$ & Pennsylvania & $11,884,314$ & $7,932,551$ \\
\hline Indiana & $5,228,156$ & $3,346,442$ & Rhode Island & 957,798 & 647,196 \\
\hline lowa & $2,846,920$ & $1,845,655$ & South Carolina & $2,617,320$ & $1,628,670$ \\
\hline Kansas & $2,265,846$ & $1,498,187$ & South Dakota & 673,247 & 422,664 \\
\hline Kentucky & $3,246,481$ & $2,099,823$ & Tennessee & $3,961,060$ & $2,590,564$ \\
\hline Louisiana & $3,672,008$ & $2,246,435$ & Texas & $11,298,787$ & $7,177,011$ \\
\hline Maine & $1,006,320$ & 647,166 & Utah & $1,067,810$ & 632,973 \\
\hline Maryland & $3,953,698$ & $2,536,241$ & Vermont & 448,327 & 286,767 \\
\hline Massachusetts & $5,726,676$ & $3,802,869$ & Virginia & $4,690,742$ & $3,051,904$ \\
\hline Michigan & $8,937,196$ & $5,611,114$ & Washington & $3,443,487$ & $2,244,939$ \\
\hline Minnesota & $3,833,173$ & $2,416,752$ & West Virginia & $1,763,331$ & $1,159,497$ \\
\hline Mississippi & $2,233,848$ & $1,367,736$ & Wisconsin & $4,447,013$ & $2,827,453$ \\
\hline \multirow[t]{4}{*}{ Missouri } & $4,718,034$ & $3,117,564$ & Wyoming & 335,719 & 212,233 \\
\hline & & & Total & $204,053,325$ & $132,750,957$ \\
\hline & & & National Ideal & & \\
\hline & & & District Size & 469,088 & 305,175 \\
\hline
\end{tabular}

Appendix Table 7. Apportionment Populations in 1980.

\begin{tabular}{lrrrlrrr}
\hline State & AP & VAP & VEP & State & AP & VAP & VEP \\
\hline Alabama & $3,890,061$ & $2,731,640$ & $2,726,249$ & Montana & 786,690 & 554,795 & 554,636 \\
Alaska & 400,481 & 271,106 & 270,122 & Nebraska & $1,570,006$ & $1,122,655$ & $1,115,142$ \\
Arizona & $2,717,866$ & $1,926,728$ & $1,890,167$ & Nevada & 799,184 & 584,694 & 573,118 \\
Arkansas & $2,285,513$ & $1,615,061$ & $1,610,104$ & New Hampshire & 920,610 & 662,528 & 660,560 \\
California & $23,668,562$ & $17,278,944$ & $15,610,966$ & New Jersey & $7,364,158$ & $5,373,962$ & $5,123,773$ \\
Colorado & $2,888,834$ & $2,081,151$ & $2,071,959$ & New Mexico & $1,299,968$ & 884,987 & 873,515 \\
Connecticut & $3,107,576$ & $2,284,657$ & $2,201,356$ & New York & $17,557,288$ & $12,870,209$ & $12,006,100$ \\
Delaware & 595,225 & 427,743 & 421,344 & North Carolina & $5,874,429$ & $4,224,031$ & $4,203,817$ \\
Florida & $9,739,992$ & $7,386,688$ & $7,088,658$ & North Dakota & 652,695 & 461,726 & 462,223 \\
Georgia & $5,464,265$ & $3,816,975$ & $3,791,652$ & Ohio & $10,797,419$ & $7,703,310$ & $7,637,813$ \\
Hawaii & 965,000 & 689,108 & 646,583 & Oklahoma & $3,025,266$ & $2,170,406$ & $2,162,051$ \\
Idaho & 943,935 & 637,270 & 633,624 & Oregon & $2,632,663$ & $1,910,048$ & $1,880,863$ \\
Illinois & $11,418,461$ & $8,183,481$ & $7,868,300$ & Pennsylvania & $11,866,728$ & $8,740,599$ & $8,664,166$ \\
Indiana & $5,490,179$ & $3,871,906$ & $3,846,321$ & Rhode Island & 947,154 & 704,303 & 675,067 \\
lowa & $2,913,387$ & $2,087,935$ & $2,070,935$ & South Carolina & $3,119,208$ & $2,179,854$ & $2,176,721$ \\
Kansas & $2,363,208$ & $1,714,644$ & $1,704,420$ & South Dakota & 690,178 & 485,162 & 484,328 \\
Kentucky & $3,661,433$ & $2,578,047$ & $2,562,572$ & Tennessee & $4,590,750$ & $3,292,560$ & $3,285,608$ \\
\hline
\end{tabular}


Appendix Table 7. Cont.

\begin{tabular}{|c|c|c|c|c|c|c|c|}
\hline State & AP & VAP & VEP & State & AP & VAP & VEP \\
\hline Louisiana & $4,203,972$ & $2,875,432$ & $2,868,792$ & Texas & $14,228,383$ & $9,923,085$ & $9,572,904$ \\
\hline Maine & $1,124,660$ & 803,273 & 799,746 & Utah & $1,461,037$ & 920,932 & 915,484 \\
\hline Maryland & $4,216,446$ & $3,049,445$ & $2,964,704$ & Vermont & 511,456 & 366,138 & 363,143 \\
\hline Massachusetts & $5,737,037$ & $4,246,648$ & $4,110,721$ & Virginia & $5,346,279$ & $3,872,484$ & $3,830,887$ \\
\hline Michigan & $9,258,344$ & $6,510,092$ & $6,374,955$ & Washington & $4,130,163$ & $2,992,796$ & $2,923,670$ \\
\hline Minnesota & $4,077,148$ & $2,904,162$ & $2,882,406$ & West Virginia & $1,949,644$ & $1,390,008$ & $1,387,231$ \\
\hline Mississippi & $2,520,638$ & $1,706,441$ & $1,704,163$ & Wisconsin & $4,705,335$ & $3,347,947$ & $3,322,053$ \\
\hline \multirow[t]{4}{*}{ Missouri } & $4,917,444$ & $3,554,203$ & $3,529,489$ & Wyoming & 470,816 & 324,004 & 326,644 \\
\hline & & & & Total & $225,867,174$ & $162,296,003$ & $157,431,825$ \\
\hline & & & & National Ideal & & & \\
\hline & & & & District Size & 519,235 & 373,094 & 361,912 \\
\hline
\end{tabular}

Appendix Table 8. Apportionment Populations in 1990.

\begin{tabular}{|c|c|c|c|c|c|c|c|}
\hline State & AP & VAP & VEP & State & $\mathrm{AP}$ & VAP & VEP \\
\hline Alabama & $4,062,608$ & $2,981,799$ & $2,956,385$ & Montana & 803,655 & 576,961 & 573,045 \\
\hline Alaska & 551,947 & 377,699 & 364,419 & Nebraska & $1,584,617$ & $1,149,373$ & $1,131,746$ \\
\hline Arizona & $3,677,985$ & $2,684,109$ & $2,523,614$ & Nevada & $1,206,152$ & 904,885 & 858,018 \\
\hline Arkansas & $2,362,239$ & $1,729,594$ & $1,710,799$ & New Hampshire & $1,113,915$ & 830,497 & 814,549 \\
\hline California & $29,839,250$ & $22,009,296$ & $18,156,500$ & New Jersey & $7,748,634$ & $5,930,726$ & $5,429,251$ \\
\hline Colorado & $3,307,912$ & $2,433,128$ & $2,366,650$ & New Mexico & $1,521,779$ & $1,068,328$ & $1,026,902$ \\
\hline Connecticut & $3,295,669$ & $2,537,535$ & $2,383,795$ & New York & $18,044,505$ & $13,730,906$ & $12,271,903$ \\
\hline Delaware & 668,696 & 502,827 & 486,760 & North Carolina & $6,657,630$ & $5,022,488$ & $4,938,968$ \\
\hline Florida & $13,003,362$ & $10,071,689$ & $9,145,312$ & North Dakota & 641,364 & 463,415 & 461,711 \\
\hline Georgia & $6,508,419$ & $4,750,913$ & $4,588,953$ & Ohio & $10,887,325$ & $8,047,371$ & $7,975,680$ \\
\hline Hawaii & $1,115,274$ & 828,103 & 770,836 & Oklahoma & $3,157,604$ & $2,308,578$ & $2,251,719$ \\
\hline Idaho & $1,011,986$ & 698,344 & 690,154 & Oregon & $2,853,733$ & $2,118,191$ & $2,057,833$ \\
\hline Illinois & $11,466,682$ & $8,484,236$ & $8,029,525$ & Pennsylvania & $11,924,710$ & $9,086,833$ & $8,962,083$ \\
\hline Indiana & $5,564,228$ & $4,088,195$ & $4,080,236$ & Rhode Island & $1,005,984$ & 777,774 & 725,084 \\
\hline lowa & $2,787,424$ & $2,057,875$ & $2,030,935$ & South Carolina & $3,505,707$ & $2,566,496$ & $2,537,384$ \\
\hline Kansas & $2,485,600$ & $1,815,960$ & $1,783,412$ & South Dakota & 699,999 & 497,542 & 494,849 \\
\hline Kentucky & $3,698,969$ & $2,731,202$ & $2,722,356$ & Tennessee & $4,896,641$ & $3,660,581$ & $3,624,940$ \\
\hline Louisiana & $4,238,216$ & $2,992,704$ & $2,959,148$ & Texas & $17,059,805$ & $12,150,671$ & $11,034,190$ \\
\hline Maine & $1,233,223$ & 918,926 & 910,982 & Utah & $1,727,784$ & $1,095,406$ & $1,086,050$ \\
\hline Maryland & $4,798,622$ & $3,619,227$ & $3,397,126$ & Vermont & 564,964 & 419,675 & 415,564 \\
\hline Massachusetts & $6,029,051$ & $4,663,350$ & $4,384,671$ & Virginia & $6,216,568$ & $4,682,620$ & $4,512,504$ \\
\hline Michigan & $9,328,784$ & $6,836,532$ & $6,693,069$ & Washington & $4,887,941$ & $3,605,305$ & $3,421,256$ \\
\hline Minnesota & $4,387,029$ & $3,208,316$ & $3,136,830$ & West Virginia & $1,801,625$ & $1,349,900$ & $1,347,723$ \\
\hline Mississippi & $2,586,443$ & $1,826,455$ & $1,824,156$ & Wisconsin & $4,906,745$ & $3,602,787$ & $3,541,548$ \\
\hline \multirow[t]{4}{*}{ Missouri } & $5,137,804$ & $3,802,247$ & $3,740,308$ & Wyoming & 455,975 & 318,063 & 312,961 \\
\hline & & & & Total & $249,022,783$ & $184,615,633$ & $173,644,393$ \\
\hline & & & & National Ideal & & & \\
\hline & & & & District Size & 572,466 & 424,404 & 399,183 \\
\hline
\end{tabular}


Appendix Table 9. Apportionment Populations in 2000.

\begin{tabular}{|c|c|c|c|c|c|c|c|}
\hline State & AP & VAP & VEP & State & $A P$ & VAP & VEP \\
\hline Alabama & $4,461,130$ & $3,323,678$ & $2,956,385$ & Montana & 905,316 & 672,133 & $\overline{573,045}$ \\
\hline Alaska & 628,933 & 436,215 & 364,419 & Nebraska & $1,715,369$ & $1,261,021$ & $1,131,746$ \\
\hline Arizona & $5,140,683$ & $3,763,685$ & $2,523,614$ & Nevada & $2,002,032$ & $1,486,458$ & 858,018 \\
\hline Arkansas & $2,679,733$ & $1,993,031$ & $1,710,799$ & New Hampshire & $1,238,415$ & 926,224 & 814,549 \\
\hline California & $33,930,798$ & $24,621,819$ & $18,156,500$ & New Jersey & $8,424,354$ & $6,326,792$ & $5,429,251$ \\
\hline Colorado & $4,311,882$ & $3,200,466$ & $2,366,650$ & New Mexico & $1,823,821$ & $1,310,472$ & $1,026,902$ \\
\hline Connecticut & $3,409,535$ & $2,563,877$ & $2,383,795$ & New York & $19,004,973$ & $14,286,350$ & $12,271,903$ \\
\hline Delaware & 785,068 & 589,013 & 486,760 & North Carolina & $8,067,673$ & $6,085,266$ & $4,938,968$ \\
\hline Florida & $16,028,890$ & $12,336,038$ & $9,145,312$ & North Dakota & 643,756 & 481,351 & 461,711 \\
\hline Georgia & $8,206,975$ & $6,017,219$ & $4,588,953$ & Ohio & $11,374,540$ & $8,464,801$ & $7,975,680$ \\
\hline Hawaii & $1,216,642$ & 915,770 & 770,836 & Oklahoma & $3,458,819$ & $2,558,294$ & $2,251,719$ \\
\hline Idaho & $1,297,274$ & 924,923 & 690,154 & Oregon & $3,428,543$ & $2,574,873$ & $2,057,833$ \\
\hline Illinois & $12,439,042$ & $9,173,842$ & $8,029,525$ & Pennsylvania & $12,300,670$ & $9,358,833$ & $8,962,083$ \\
\hline Indiana & $6,090,782$ & $4,506,089$ & $4,080,236$ & Rhode Island & $1,049,662$ & 800,497 & 725,084 \\
\hline lowa & $2,931,923$ & $2,192,686$ & $2,030,935$ & South Carolina & $4,025,061$ & $3,002,371$ & $2,537,384$ \\
\hline Kansas & $2,693,824$ & $1,975,425$ & $1,783,412$ & South Dakota & 756,874 & 552,195 & 494,849 \\
\hline Kentucky & $4,049,431$ & $3,046,951$ & $2,722,356$ & Tennessee & $5,700,037$ & $4,290,762$ & $3,624,940$ \\
\hline Louisiana & $4,480,271$ & $3,249,177$ & $2,959,148$ & Texas & $20,903,994$ & $14,965,061$ & $11,034,190$ \\
\hline Maine & $1,277,731$ & 973,685 & 910,982 & Utah & $2,236,714$ & $1,514,471$ & $1,086,050$ \\
\hline Maryland & $5,307,886$ & $3,940,314$ & $3,397,126$ & Vermont & 609,890 & 461,304 & 415,564 \\
\hline Massachusetts & $6,355,568$ & $4,849,033$ & $4,384,671$ & Virginia & $7,100,702$ & $5,340,253$ & $4,512,504$ \\
\hline Michigan & $9,955,829$ & $7,342,677$ & $6,693,069$ & Washington & $5,908,684$ & $4,380,278$ & $3,421,256$ \\
\hline Minnesota & $4,925,670$ & $3,632,585$ & $3,136,830$ & West Virginia & $1,813,077$ & $1,405,951$ & $1,347,723$ \\
\hline Mississippi & $2,852,927$ & $2,069,471$ & $1,824,156$ & Wisconsin & $5,371,210$ & 3,994,919 & $3,541,548$ \\
\hline \multirow[t]{4}{*}{ Missouri } & $5,606,260$ & $4,167,519$ & $3,740,308$ & Wyoming & 495,304 & 364,909 & 312,961 \\
\hline & & & & Total & $281,424,177$ & $208,671,027$ & $173,644,393$ \\
\hline & & & & National Ideal & & & \\
\hline & & & & District Size & 646,952 & 479,704 & 399,183 \\
\hline
\end{tabular}

Appendix Table 10. Apportionment Populations in 2000.

\begin{tabular}{lrrrlrrr}
\hline State & AP & VAP & VEP & State & AP & VAP & VEP \\
\hline Alabama & $4,779,736$ & $3,647,277$ & $3,472,784$ & Montana & 989,415 & 765,852 & 758,805 \\
Alaska & 710,231 & 522,853 & 492,159 & Nebraska & $1,826,341$ & $1,367,120$ & $1,305,876$ \\
Arizona & $6,392,017$ & $4,763,003$ & $4,220,784$ & Nevada & $2,700,551$ & $2,035,543$ & $1,750,950$ \\
Arkansas & $2,915,918$ & $2,204,443$ & $2,081,031$ & New Hampshire & $1,316,470$ & $1,029,236$ & $1,000,167$ \\
California & $37,253,956$ & $27,958,916$ & $22,921,454$ & New Jersey & $8,791,894$ & $6,726,680$ & $5,819,152$ \\
Colorado & $5,029,196$ & $3,803,587$ & $3,529,590$ & New Mexico & $2,059,179$ & $1,540,507$ & $1,407,025$ \\
Connecticut & $3,574,097$ & $2,757,082$ & $2,514,825$ & New York & $19,378,102$ & $15,053,173$ & $13,121,745$ \\
Delaware & 897,934 & 692,169 & 648,840 & North Carolina & $9,535,483$ & $7,253,848$ & $6,791,748$ \\
Florida & $18,801,310$ & $14,799,219$ & $12,939,596$ & North Dakota & 672,591 & 522,720 & 517,347 \\
Georgia & $9,687,653$ & $7,196,101$ & $6,464,406$ & Ohio & $11,536,504$ & $8,805,753$ & $8,568,112$ \\
Hawaii & $1,360,301$ & $1,056,483$ & 960,041 & Oklahoma & $3,751,351$ & $2,821,685$ & $2,669,051$ \\
Idaho & $1,567,582$ & $1,138,510$ & $1,071,526$ & Oregon & $3,831,074$ & $2,964,621$ & $2,762,313$ \\
Illinois & $12,830,632$ & $9,701,453$ & $8,788,929$ & Pennsylvania & $12,702,379$ & $9,910,224$ & $9,567,164$ \\
Indiana & $6,483,802$ & $4,875,504$ & $4,698,660$ & Rhode Island & $1,052,567$ & 828,611 & 762,810 \\
lowa & $3,046,355$ & $2,318,362$ & $2,232,917$ & South Carolina & $4,625,364$ & $3,544,890$ & $3,387,826$ \\
Kansas & $2,853,118$ & $2,126,179$ & $2,009,563$ & South Dakota & 814,180 & 611,383 & 599,838 \\
\hline
\end{tabular}




\section{COGITATIO}

Appendix Table 10. Cont.

\begin{tabular}{|c|c|c|c|c|c|c|c|}
\hline State & AP & VAP & VEP & State & AP & VAP & VEP \\
\hline Kentucky & $4,339,367$ & $3,315,996$ & $3,198,138$ & Tennessee & $6,346,105$ & $4,850,104$ & $4,621,221$ \\
\hline Louisiana & $4,533,372$ & $3,415,357$ & $3,246,213$ & Texas & $25,145,561$ & $18,279,737$ & $15,492,550$ \\
\hline Maine & $1,328,361$ & $1,053,828$ & $1,038,335$ & Utah & $2,763,885$ & $1,892,858$ & $1,776,843$ \\
\hline Maryland & $5,773,552$ & $4,420,588$ & $3,999,682$ & Vermont & 625,741 & 496,508 & 489,123 \\
\hline Massachusetts & $6,547,629$ & $5,128,706$ & $4,681,091$ & Virginia & $8,001,024$ & $6,147,347$ & $5,658,358$ \\
\hline Michigan & $9,883,640$ & $7,539,572$ & $7,248,403$ & Washington & $6,724,540$ & $5,143,186$ & $4,724,989$ \\
\hline Minnesota & $5,303,925$ & $4,019,862$ & $3,803,802$ & West Virginia & $1,852,994$ & $1,465,576$ & $1,442,796$ \\
\hline Mississippi & $2,967,297$ & $2,211,742$ & $2,131,049$ & Wisconsin & $5,686,986$ & $4,347,494$ & $4,174,726$ \\
\hline \multirow[t]{3}{*}{ Missouri } & $5,988,927$ & $4,563,491$ & $4,365,737$ & Wyoming & 563,626 & 428,224 & 416,693 \\
\hline & & & & Total & $308,143,815$ & $234,063,163$ & $212,346,783$ \\
\hline & & & & $\begin{array}{l}\text { National Ideal } \\
\text { District Size }\end{array}$ & 708,377 & 538,076 & 488,154 \\
\hline
\end{tabular}

